\title{
Recent Trends in Sustainable Remediation of Pb-Contaminated Shooting Range Soils: Rethinking Waste Management within a Circular Economy
}

\author{
María T. Gómez-Sagasti ${ }^{1, *}$, Mikel Anza ${ }^{2}\left(\mathbb{D}\right.$, June Hidalgo $^{2}\left(\mathbb{D}\right.$, Unai Artetxe ${ }^{1}$, Carlos Garbisu ${ }^{2}(\mathbb{D}$ \\ and José M. Becerril ${ }^{1}$ \\ 1 Department of Plant Biology and Ecology, University of the Basque Country (UPV/EHU), P.O. Box 644, \\ E-48080 Bilbao, Spain; unai.artetxe@ehu.eus (U.A.); josemaria.becerril@ehu.eus (J.M.B.) \\ 2 NEIKER-BRTA, Department of Conservation of Natural Resources, c/Berreaga 1, E-48160 Derio, Spain; \\ manza@neiker.eus (M.A.); jhidalgo@neiker.eus (J.H.); cgarbisu@neiker.eus (C.G.) \\ * Correspondence: mariateresa.gomez@ehu.eus
}

\section{check for} updates

Citation: Gómez-Sagasti, M.T.; Anza, M.; Hidalgo, J.; Artetxe, U.; Garbisu, C.; Becerril, J.M. Recent Trends in Sustainable Remediation of $\mathrm{Pb}$-Contaminated Shooting Range Soils: Rethinking Waste Management within a Circular Economy. Processes 2021, 9, 572. https://doi.org/ $10.3390 /$ pr9040572

Academic Editors: Alazne Gutiérrez and Roberto Palos

Received: 5 March 2021

Accepted: 22 March 2021

Published: 25 March 2021

Publisher's Note: MDPI stays neutral with regard to jurisdictional claims in published maps and institutional affiliations.

Copyright: (c) 2021 by the authors. Licensee MDPI, Basel, Switzerland. This article is an open access article distributed under the terms and conditions of the Creative Commons Attribution (CC BY) license (https:// creativecommons.org/licenses/by/ $4.0 /)$.

\begin{abstract}
Soil metal contamination in recreational shooting ranges represents a widespread environmental problem. Lead $(\mathrm{Pb})$ is the primary component of traditional ammunition, followed by metalloids such as antimony ( $\mathrm{Sb}$ ) and arsenic (As). Lead-based bullets and pellets deposited on the soil surface are subject to steady weathering; hence, metal(loid)s are released and accumulated in the underlying soil, with potential adverse consequences for ecosystem function and human health. Amongst the currently available environmentally-safe technologies for the remediation of metal-contaminated soils, chemical immobilization is recognized as the most practical and costeffective one. This technology often uses inorganic and organic amendments to reduce metal mobility, bioavailability and toxicity (environmental benefits). Likewise, amendments may also promote and speed up the re-establishment of vegetation on metal-affected soils, thus facilitating the conversion of abandoned shooting ranges into public green spaces (social benefit). In line with this, the circular economy paradigm calls for a more sustainable waste management, for instance, by recycling and reusing by-products and wastes in an attempt to reduce the demand for raw materials (economic benefit). The objective of this manuscript is to present a state-of-the-art review of the different industrial and agro-food by-products and wastes used for the remediation of metal-contaminated shooting range soils.
\end{abstract}

Keywords: lead contamination; chemical immobilization; industrial and agro-food wastes; soil amendments; waste management

\section{Introduction}

The environmental impact of metal contamination from legacy shooting activities is of growing concern in modern society. Many studies have evidenced that outdoor shooting ranges used for military training or sport can constitute a significant source of metal contamination [1-4], with unintended consequences for ecosystem and human health [5-7]. In shooting ranges, soil metal contamination occurs primarily through the use of lead-core bullets and pellets. Regular ammunition used in shooting ranges typically contains lead $(\mathrm{Pb} ;>90 \%$ in weight), metalloids such as antimony (Sb;2-7\%) and arsenic (As; $0.5-2 \%$ ) as well as varying amounts of nickel $(\mathrm{Ni})$, zinc $(\mathrm{Zn})$ and copper $(\mathrm{Cu})[2,8,9]$. Although so-called environmentally friendly ("green") ammunition, made of tungsten and nylon, has been recently introduced, large amounts of $\mathrm{Pb}$-containing bullets are still used due to their high ballistic coefficient [10].

Following shooting activity, $\mathrm{Pb}$ bullet fragments and pellets are spread over the shooting range and its vicinity [11]. In the United States, 60,000 tonnes of $\mathrm{Pb}$ are deposited annually onto shooting range soils [9]. In Finland, Sweden and Switzerland, it is estimated 
that the total annual $\mathrm{Pb}$ load in site-specific shooting ranges is about 500 tonnes. Very often, after the abandonment of a shooting range, pellets are left on the soil, and then, as a result of continuous weathering and corrosion of ammunition residues, total $\mathrm{Pb}$ concentrations in surface soils of shooting ranges frequently rise above $1000 \mathrm{mg} \mathrm{kg}^{-1}$ (and often well over 10,000 mg kg-1) [11-16]. These values are far higher than the regulatory limit of $300 \mathrm{mg} \mathrm{Pb} \mathrm{kg}{ }^{-1}$ soil as prescribed in the European Council Directive (1986) [17] and also exceed the total screening criterion of $400 \mathrm{mg} \mathrm{Pb} \mathrm{kg}^{-1}$ soil as established by the U.S. Environmental Protection Agency (US EPA, 1996) [18], which provide reference points for establishing remediation targets. On the other hand, quantitative risk assessment (QRA) is an essential tool for the estimation of environmental and human risks associated with soil contamination, which helps to make appropriate decisions for soil remediation.

The physical elimination of bullet fragments and pellets from soil includes separation techniques or soil excavation and landfill disposal [19]. These traditional practices are very costly and environmentally destructive [20-22], and therefore are not feasible on a large scale $[23,24]$. Heavily contaminated soils $\left(>2000 \mathrm{mg} \mathrm{Pb} \mathrm{kg}^{-1}\right)$ from inactive or abandoned shooting ranges are usually landfilled or processed by chemical washing, whereas for moderately contaminated soils $\left(<2000 \mathrm{mg} \mathrm{Pb} \mathrm{kg}^{-1}\right)$, cost-effective remediation strategies are often sought [24]. Metal soil remediation strategies can be aimed at (i) stabilizing/immobilizing the metal (strategy: immobilization) or (ii) reducing its concentration (strategy: mobilization and then removal) [19]. The immobilization strategy, which can include chemical immobilization and/or phytostabilization [25-27], seeks to reduce metal bioavailability. Many remediation initiatives dealing with diffuse contamination by metals with reduced mobility, such as $\mathrm{Pb}$, are based on this strategy. Mobilization, on the other hand, involves the addition of a chemical agent to the contaminated soil in order to increase metal bioavailability and mobility for its subsequent elimination/extraction from the soil. Mobilization-based techniques include soil washing and assisted phytoextraction [27,28]. This latter strategy is commonly implemented when dealing with discrete, localized metal contamination.

Phytoremediation (via phytostabilization or phytoextraction) is an affordable and environmentally friendly technology for soil remediation and is applicable when metals are located in the rhizosphere $[29,30]$. However, the in situ phytoremediation of shooting range soils remains poorly documented [31]. Wilde et al. (2005) [30] found that the combined use of vetiver grass (Chrysopogon zizanioides) and a fertilizer reduced plant uptake of soil $\mathrm{Pb}$, thus decreasing the associated environmental risks. Rodríguez-Seijo et al. (2016) [10] reported the remarkable $\mathrm{Pb}$-phytostabilization capacity of Agrostis capillaris plants when grown in shooting range soil. Tariq and Ashraf (2016) [32] showed that pea (Pisum sativum) and sunflower (Helianthus annuus) plants efficiently removed $\mathrm{Pb}$ from a shooting range soil contaminated with $\mathrm{Cd}, \mathrm{Cu}, \mathrm{Co}, \mathrm{Ni}, \mathrm{Cr}$ and $\mathrm{Pb}$. Nonetheless, phytoremediation (mainly phytoextraction) generates metal-contaminated plant biomass, which requires further treatment for safe disposal, recycling or reuse. Interestingly, the combination of metal phytoextraction with ecocatalysis, an innovative biomass processing technology [33,34], allows the use of the metal-laden plant biomass, resulting from phytoextraction, as an effective industrial ecocatalyst, thus enhancing the financial viability of such phytotechnology [35].

The intended alteration of metal $(\mathrm{Pb})$ bioavailability by the addition of chemical amendments represents an effective means of mitigating environmental risks without the high costs usually associated with unsustainable traditional remediation strategies [28]. Contaminated shooting range soils have been mainly treated with a variety of inorganic amendments (Table 1), which can be either synthetic or mined materials, such as phosphates [36-42], lime-based compounds [43,44], and metal oxides [24,37,45], in order to induce specific reactions within the soil components to render $\mathrm{Pb}$ inert without substantially affecting soil properties [28]. The chemical reactions involved in $\mathrm{Pb}$ immobilization by the abovementioned amendments are summarized in Table 2 . 
Table 1. Inorganic materials used as amendments for $\mathrm{Pb}$ immobilization in shooting range soils.

\begin{tabular}{|c|c|c|c|c|c|}
\hline $\begin{array}{l}\text { Type of Soil } \\
\text { Amendment }\end{array}$ & Material & Reference & Type of Study (Duration) & Treatment Rates & $\begin{array}{l}\text { Range of Soil [Total Pb] * } \\
\left(\mathrm{mg} \mathrm{kg}^{-1}\right)\end{array}$ \\
\hline \multirow{8}{*}{$\begin{array}{l}\text { Phosphate } \\
\text { amendments }\end{array}$} & $\begin{array}{c}\text { Tricalcium phosphate }\left(\mathrm{Ca}_{3}\left(\mathrm{PO}_{4}\right)_{2}\right) \text {, } \\
\text { hydroxyapatite, rock phosphate and } \\
\text { potassium dihydrogen phosphate } \\
\left(\mathrm{KH}_{2} \mathrm{PO}_{4}\right)\end{array}$ & Park et al. (2011) [46] & $\mathrm{Lab}(14 \mathrm{~d})$ & $200 \mathrm{mg} \mathrm{P} \mathrm{kg}^{-1}$ soil & 346 \\
\hline & $\begin{array}{l}\text { Soft rock phosphate and phosphoric } \\
\text { acid }\end{array}$ & $\begin{array}{l}\text { Sanderson et al. (2015) [38] } \\
\text { Sanderson et al. (2014) [47] }\end{array}$ & Lab (12 mth) & $\begin{array}{c}\text { 1:1 proportion } \\
\mathrm{P} / \mathrm{Pb} \text { molar ratio of } 5: 1\end{array}$ & $\begin{array}{c}399-10,403 \\
2330-12,167\end{array}$ \\
\hline & $\begin{array}{c}\text { Commercial phosphate-based } \\
\text { amendment }\end{array}$ & $\begin{array}{l}\text { Sanderson et al. (2015) [38] } \\
\text { Sanderson et al. (2014) [47] }\end{array}$ & Lab (12 mth) & $\begin{array}{c}0.5,1 \text { and } 2 \%(w / w) \\
\mathrm{P} / \mathrm{Pb} \text { molar ratio of } 5: 1\end{array}$ & $\begin{array}{l}399-10,403 \\
2330-12,167\end{array}$ \\
\hline & Phosphoric acid & Sanderson et al. (2015) [37] & Lab (1 mth) & $1 \%(w / w)$ & $446-8409$ \\
\hline & $\begin{array}{l}\text { Monocalcium phosphate } \\
\quad\left(\mathrm{Ca}\left(\mathrm{H}_{2} \mathrm{PO}_{4}\right)_{2} \cdot \mathrm{H}_{2} \mathrm{O}\right)\end{array}$ & $\begin{array}{c}\text { Cao et al. (2008) [43] } \\
\text { Sanderson et al. (2016) [48] }\end{array}$ & $\begin{array}{l}\text { Lab (28 d) } \\
\operatorname{Lab}(7 \mathrm{~d})\end{array}$ & $\begin{array}{c}2.5,5.0,7.5, \text { and } 10 \%(w / w) \\
2 \%(w / w)\end{array}$ & $\begin{array}{l}2500-35,868 \\
177-2545\end{array}$ \\
\hline & $\begin{array}{l}\text { Calcium phosphate }\left(\mathrm{Ca}_{3}\left(\mathrm{PO}_{4}\right)_{2}\right) \\
\text { nanoparticles }\end{array}$ & Arenas-Lagos et al. (2016) [39] & $\operatorname{Lab}(10 \mathrm{~d})$ & $5 \%(w / w)$ & $223-6309$ \\
\hline & $\begin{array}{l}\text { Diammonium phosphate, } \\
\text { phosphate rocks }\end{array}$ & Seshadri et al. (2017) [40] & $\mathrm{Lab}(30 \mathrm{~d})$ & $600 \mathrm{mg} \mathrm{P} \mathrm{kg}^{-1} \mathrm{DW}$ soil & 9876 \\
\hline & Phosphate rock and phosphoric acid & Fayiga and Saha (2017) [41] & Lab (18 h) & $\mathrm{P} / \mathrm{Pb}$ molar ratio of $4: 1$ & 739-8014 \\
\hline \multirow{5}{*}{ Lime-based amendments } & $\begin{array}{c}\text { Calcium oxide }(\mathrm{CaO}) \\
* \text { Commonly known as quicklime }\end{array}$ & Cao et al. (2008) [43] & $\mathrm{Lab}(28 \mathrm{~d})$ & $2.5,5.0,7.5$, and $10 \%(w / w)$ & $2500-35,868$ \\
\hline & $\begin{array}{l}\text { Calcium hydroxide }\left(\mathrm{Ca}(\mathrm{OH})_{2}\right){ }^{*} \\
{ }^{*} \text { Commonly known as slaked lime }\end{array}$ & Conesa et al. (2012) [44] & $\operatorname{Lab}(14 \mathrm{~d})$ & $5.5 \mathrm{~g} \mathrm{Ca}(\mathrm{OH})_{2} \mathrm{~kg}^{-1} \mathrm{DW}$ soil & 620 \\
\hline & \multirow{3}{*}{$\begin{array}{l}\text { Calcium carbonate }\left(\mathrm{CaCO}_{3}\right)^{*} \\
{ }^{*} \text { Commonly known as lime }\end{array}$} & Sanderson et al. (2015) [38] & \multirow{2}{*}{ Lab (12 mth) } & $0.5,1$, and $2 \%(w / w)$ & $399-10,403$ \\
\hline & & Sanderson et al. (2014) [47] & & $5 \%(w / w)$ & $2330-12,167$ \\
\hline & & $\begin{array}{c}\text { Levonmäki and Hartikainen } \\
\text { (2007) [49] }\end{array}$ & $\mathrm{Lab}(21 \mathrm{~d})$ & $5 \mathrm{tha}^{-1}$ & 22,600 \\
\hline
\end{tabular}


Table 1. Cont.

\begin{tabular}{|c|c|c|c|c|c|}
\hline $\begin{array}{l}\text { Type of Soil } \\
\text { Amendment }\end{array}$ & Material & Reference & Type of Study (Duration) & Treatment Rates & $\begin{array}{c}\text { Range of Soil [Total Pb] * } \\
\left(\mathrm{mg} \mathrm{kg}^{-1}\right)\end{array}$ \\
\hline \multirow{5}{*}{ Metal oxide-based amendments } & $\begin{array}{l}\text { Natural iron oxide (FeO), gibbsite } \\
\text { (GINP), and silver nanomaterial } \\
\text { (AgNP) }\end{array}$ & Rajapaksha et al. (2015) [24] & Lab (12 mth) & $0.1 \%(w / w)$ & 17,468 \\
\hline & \multirow{3}{*}{ Magnesium oxide $(\mathrm{MgO})$} & Sanderson et al. (2015) [37] & Lab (1 mth) & $10 \%(w / w)$ & $446-8409$ \\
\hline & & Sanderson et al. (2015) [38] & Lab (12 mth) & $0.5,1$, and $2 \%(w / w)$ & $399-10,403$ \\
\hline & & Sanderson et al. (2014) [47] & Lab (12 mth) & $2 \%(w / w)$ & $2330-12,167$ \\
\hline & Iron (III) oxide $\left(\mathrm{Fe}_{2} \mathrm{O}_{3}\right)$ nanoparticles & Rodríguez-Seijo et al. (2020) [42] & $\mathrm{Lab}(10 \mathrm{~d})$ & $5 \%(w / w)$ & $507-4452$ \\
\hline
\end{tabular}

${ }^{*}$ Range of soil total $\mathrm{Pb}$ concentration $\left(\mathrm{mg} \mathrm{kg}^{-1}\right)$ min-max averages. 
Table 2. Chemical reactions involved in the immobilization mechanisms of $\mathrm{Pb}^{2+}[13,37,38,50,51]$.

\begin{tabular}{|c|c|}
\hline Material & Chemical Equation \\
\hline Hydroxyapatite & $\begin{array}{l}\mathrm{Ca}_{10}\left(\mathrm{PO}_{4}\right)_{6}(\mathrm{OH})_{2}(\mathrm{~s})+14 \mathrm{H}^{+} \rightarrow 10 \mathrm{Ca}^{2+}+6 \mathrm{H}_{2} \mathrm{PO}_{4}^{-}+2 \mathrm{H}_{2} \mathrm{O} \text { (dissolution of hydroxyapatite) } \\
10 \mathrm{~Pb}^{2+}+6 \mathrm{H}_{2} \mathrm{PO}_{4}^{-}+2 \mathrm{H}_{2} \mathrm{O} \rightarrow \mathrm{Pb}_{10}\left(\mathrm{PO}_{4}\right)_{6}(\mathrm{OH})_{2}(\mathrm{~s})+14 \mathrm{H}^{+} \text {(precipitation of pyromorphite) }\end{array}$ \\
\hline Phosphoric acid & $5 \mathrm{~Pb}^{2+}+3 \mathrm{H}_{2} \mathrm{PO}_{4}^{-}+\mathrm{Cl}^{-} \rightarrow \mathrm{Pb}_{5}\left(\mathrm{PO}_{4}\right)_{3} \mathrm{Cl}(\mathrm{s})+6 \mathrm{H}^{+}$ \\
\hline Phosphate rock & $\begin{array}{l}\mathrm{Ca}_{10}\left(\mathrm{PO}_{4}\right)_{6} \mathrm{~F}_{2}+12 \mathrm{H}^{+} \rightarrow 10 \mathrm{Ca}^{2+}+6 \mathrm{H}_{2} \mathrm{PO}_{4}^{-}+2 \mathrm{~F}^{-} \text {(dissolution of phosphate rock) } \\
10 \mathrm{~Pb}^{2+}+6 \mathrm{H}_{2} \mathrm{PO}_{4}^{-}+2 \mathrm{~F}^{-} \rightarrow \mathrm{Pb}_{10}\left(\mathrm{PO}_{4}\right)_{6} \mathrm{~F}_{2}+12 \mathrm{H}^{+} \text {(precipitation of fluoropyromorphite) }\end{array}$ \\
\hline Diammonium phosphate & $\begin{array}{l}\left(\mathrm{NH}_{4}\right) 2 \mathrm{HPO}_{4}+\mathrm{Ca}^{2+}+2 \mathrm{H}_{2} \mathrm{O} \rightarrow \mathrm{CaHPO}_{4} \cdot 2 \mathrm{H}_{2} \mathrm{O}+2 \mathrm{NH}_{4}^{+} \\
4 \mathrm{CaHPO}_{4} \cdot 2 \mathrm{H}_{2} \mathrm{O}+\mathrm{H}_{2} \mathrm{O} \rightarrow \mathrm{Ca}_{4} \mathrm{H}\left(\mathrm{PO}_{4}\right)_{3} \cdot 3 \mathrm{H}_{2} \mathrm{O}+\mathrm{H}_{3} \mathrm{PO}_{4} \text { (phosphoric acid) }\end{array}$ \\
\hline Magnesium oxide & $\begin{array}{l}\mathrm{MgO}+\mathrm{H}_{2} \mathrm{O} \rightarrow \mathrm{Mg}(\mathrm{OH})_{2} ; \mathrm{Mg}(\mathrm{OH})_{2}+\mathrm{H}_{2} \mathrm{O} \rightarrow \mathrm{Mg}^{2+}+2 \mathrm{OH}^{-} \\
\mathrm{Pb}^{2+}+2 \mathrm{OH}^{-} \rightarrow \mathrm{Pb}(\mathrm{OH})_{2} \\
\mathrm{MgO}+\mathrm{Pb}^{2+} \rightarrow \mathrm{PbO}+\mathrm{Mg}^{2+}\end{array}$ \\
\hline Calcium carbonate & $\begin{array}{l}\mathrm{CaCO}_{3}(\mathrm{~s})+\mathrm{H}_{2} \mathrm{O} \rightarrow \mathrm{Ca}^{2+}+\mathrm{CO}_{2}(\mathrm{~g})+2 \mathrm{OH}^{-} \\
\mathrm{CaCO}_{3}+2 \mathrm{H}_{2} \mathrm{O}+\mathrm{Pb}^{2+} \rightarrow \mathrm{Pb}\left(\mathrm{CO}_{3}\right) \text { (cerussite) }+\mathrm{Ca}(\mathrm{OH})_{2}+2 \mathrm{H}^{+} \\
3 \mathrm{~Pb}\left(\mathrm{CO}_{3}\right)+2 \mathrm{H}_{2} \mathrm{O} \rightarrow \mathrm{Pb}_{3}\left(\mathrm{CO}_{3}\right)_{2}(\mathrm{OH})_{2}(\mathrm{~s}) \text { (hydrocerussite) }+\mathrm{H}_{2} \mathrm{CO}_{3}\end{array}$ \\
\hline Calcium oxide & $\begin{array}{l}\mathrm{CaO}(\mathrm{s})+\mathrm{H}_{2} \mathrm{O} \rightarrow \mathrm{Ca}(\mathrm{OH})_{2} \rightarrow \mathrm{Ca}^{2+}+2 \mathrm{OH}^{-} \\
\mathrm{Pb}{ }^{2+}+2 \mathrm{OH}^{-} \rightarrow \mathrm{Pb}(\mathrm{OH})_{2} \\
\mathrm{CaO}+\mathrm{Pb}^{2+} \rightarrow \mathrm{PbO}(\mathrm{s})(\text { litharge })+\mathrm{Ca}^{2+} \\
\mathrm{PbO}+\mathrm{CO}_{2}(\mathrm{~g})+2 \mathrm{H}_{2} \mathrm{O} \rightarrow \mathrm{PbCO}_{3}(\mathrm{~s}) \text { (cerussite) }+2 \mathrm{OH}^{-}+\mathrm{H}_{2}\end{array}$ \\
\hline
\end{tabular}

More recently, industrial and agro-food by-products and wastes are being considered as soil ameliorants or amendments. According to the European Waste Framework Directive (WFD) (2008) [52], "waste" is any substance or object that the holder discards or intends or is required to discard and "by-product", in contrast, is a material that is not deliberately generated in a production process, which may or may not be a waste and which can be used directly without any further processing other than normal industrial practice.

As a result of human economic activities, huge quantities of these materials are constantly being produced. In the absence of proper management, these materials can become a serious environmental problem. Many governments and industries throughout the world are becoming increasingly interested in diverting by-products and wastes from landfills, and instead are adopting the "reduce, reuse, repair, recycle" hierarchy of waste management. This has more recently been included in the principles of the European Circular Economy Strategy [53] as well as in the Sustainable Development Goals of the 2030 Agenda for Sustainable Development of the United Nations [54] Goal No. 12: "Responsible consumption and production". The circular economy is considered to be an umbrella concept for an economy that fosters the sustainable and cyclical use of resources, thus minimizing waste generation [55]. More sustainable resource and waste management is also a strategic target of the European Green Deal [56-58].

The purpose of the present paper is to provide an overview of recent industrial and agro-food by-products and wastes that are being used as amendments for the remediation of $\mathrm{Pb}$-contaminated shooting range soils, within the context of the circular economy paradigm. Likewise, it aims to assist decision-makers involved in the remediation of contaminated shooting ranges according to circular economy values. Finally, as an example, an experiment focused on the use of agro-food by-products and wastes as amendments for the remediation of a $\mathrm{Pb}$-contaminated shooting range soil is presented. The main objective of this experiment was to evaluate the effectiveness of such amendments in terms of the reduction of soil extractable $\mathrm{Pb}$ under both laboratory and field conditions. 


\section{From Wastes to Resources: By-Products and Wastes as Pb-Immobilizing Agents in Shooting Range Soils}

Heavy metal lead $(\mathrm{Pb})$ ranks second, after $\mathrm{As}$, on the priority lists of Hazardous Substances of the Agency for Toxic Substances and Disease Registry (ATSDR) and the US Environmental Protection Agency (US EPA) due to its widespread occurrence and, above all, its potential high ecotoxicity [13]. Lead is also recognized as a chemical of great concern in the European REACH Regulation (EC 1907/2006; Registration, Evaluation, Authorization, and Restriction of Chemicals) [59]. In shooting ranges, $\mathrm{Pb}$ toxicity is related to the constant weathering of ammunition, which increases its presence in the soil matrix $[60,61]$. Under certain soil conditions (i.e., depending on the values of soil $\mathrm{pH}$, organic matter content, cation-exchange capacity, redox potential, clay mineral content, etc.) [62], soil $\mathrm{Pb}$ will undergo oxidation $[\mathrm{PbO}]$, carbonation $\left[\mathrm{Pb}\left(\mathrm{CO}_{3}\right)_{2}\right]$ and/or hydration processes $\left[\mathrm{Pb}\left(\mathrm{CO}_{3}\right)_{2}(\mathrm{OH})_{2}\right]$, leading to a possible increase in $\mathrm{Pb}$ mobility and bioavailability [63]. It is therefore essential to understand the geochemical behavior of $\mathrm{Pb}$ in shooting range soils in order to manage, and preferably reduce, potential risks for humans and the environment [19]. Soluble $\mathrm{Pb}$ can bioaccumulate in living organisms, thus causing toxic effects on terrestrial and aquatic biota at different trophic levels [4,64], and references therein]. It is widely recognized that $\mathrm{Pb}$ can affect plant performance [65] and reduce the biomass, activity and diversity of soil microorganisms, which are key to soil fertility and health [66]. The major impact on soil biota is expected to result from the unintended ingestion of $\mathrm{Pb}$ by consumption of soil, plants and water $[4,67]$. Moreover, as many shooting ranges are commonly located near urban and/or agricultural areas $[9,10,68]$, they also represent a high risk of $\mathrm{Pb}$ migration to humans through metal-soil-crop interactions [61].

Lead has a prolonged persistence in the environment (it is non-degradable) [69], tends to form relatively stable complexes with organic and inorganic soil ligands, and is soluble only within a limited acidic $\mathrm{pH}$ range [4]. The water-soluble and exchangeable forms of metals in soils broadly determine their mobility and bioavailability (frequently considered as proxy for toxicity) [70]. Therefore, soil $\mathrm{Pb}$ generally shows restricted mobility, solubility and bioavailability [71,72]. However, its low solubility does not completely prevent groundwater contamination via $\mathrm{Pb}$ leaching $[47,64,73,74]$, and references therein]. The abovementioned long residence time of $\mathrm{Pb}$ in shooting range soil makes it a long-term environmental threat for ecosystems and human health, as potential adverse effects on soil biological and physico-chemical properties can persist for centuries [73].

The environmental impact of $\mathrm{Pb}$-contaminated shooting range soils usually varies from site to site, owing to variations in soil conditions and $\mathrm{Pb}$ speciation, as well as depending on the capacity of the local biota to absorb, bioaccumulate and biomagnify toxic $\mathrm{Pb}[47,75]$. Risk assessment of shooting ranges has been undertaken in many studies $[47,76,77]$ using selected representative (and sensitive) species to examine and quantify the potential toxic effects of $\mathrm{Pb}$ and co-contaminants. Recent studies have examined the beneficial effects of different remediation strategies on these biological endpoints [20,47,78]. After all, for a direct and proper determination of contaminant-induced adverse biological effects, biological measurements are needed, as chemical measurements of extractability and bioavailability (frequently considered as proxies for contaminant toxicity) are questionable estimations [79].

Among the remediation technologies that have been developed and traditionally implemented for the clean-up of metal-polluted soils, in situ strategies such as chemical immobilization through the use of industrial and agro-food by-products and wastes (preferably, of local origin) are most promising to achieve an environmentally sound, cost-effective remediation of $\mathrm{Pb}$-contaminated shooting range soils. These by-products and wastes offer the following advantages: (1) they can make $\mathrm{Pb}$ less bioavailable and thus minimize the risks to environmental and human health; (2) they can improve soil physico-chemical and biological properties and, hence, soil fertility and vegetation re-establishment; (3) their use as soil amendments provides additional environmental (i.e., recycling and reutiliza- 
tion) $[80,81]$ and economic (i.e., avoids costs associated with treatment and landfill disposal) benefits.

As previously stated, industrial and agro-food by-products and wastes are currently considered valuable immobilizing agents for the remediation of $\mathrm{Pb}$-contaminated shooting range soils [82]. Promising outcomes have been observed using inorganic wastes, such as fly ash, mud or red mud, and furnace slag, as soil amendments (Table 3A). Soil amendments from biological origins, such as oyster shells, egg shells, plant remains and biochar, have also been successfully used for the remediation of $\mathrm{Pb}$ contaminated soils (Table 3B). The fact that these materials are often easily available and/or have a relatively low cost, together with the abovementioned environmental and social benefits, has encouraged their use for the in situ immobilization of metal contaminants in shooting range soils. 
Table 3. Industrial (A) and agro-food (B) by-products and wastes used as amendments for Pb immobilization in shooting range soils.

\begin{tabular}{|c|c|c|c|c|c|c|}
\hline \multicolumn{7}{|c|}{ A. Industrial By-Products and Wastes Used as Inorganic Soil Amendments } \\
\hline Type of Amendment & Activity & By-Product or Waste & Reference & $\begin{array}{l}\text { Type of Study } \\
\text { (Duration) }\end{array}$ & Treatment Rates & $\begin{array}{c}\text { Range of Soil [Total Pb] * } \\
\left(\mathrm{mg} \mathrm{kg}^{-1}\right)\end{array}$ \\
\hline \multirow{4}{*}{$\begin{array}{l}\text { Metal oxide-based } \\
\text { amendments }\end{array}$} & Coal burning & Fly ash & Moon et al. (2013) [80] & $\operatorname{Lab}(7 \mathrm{~d})$ & (L:S) ratio of 0.2 & 7996 \\
\hline & \multirow{2}{*}{ Alumina extraction } & \multirow{2}{*}{ Red mud } & Sanderson et al. (2015) [38] & \multirow{2}{*}{ Lab (12 mth) } & $0.5,1$, and $2 \%$ & $399-10,403$ \\
\hline & & & Sanderson et al. (2014) [47] & & $2 \%(w / w)$ & $2330-12,167$ \\
\hline & Blast furnace & Furnace slag & $\begin{array}{l}\text { Levonmäki and Hartikainen } \\
\text { (2007) [49] }\end{array}$ & $\operatorname{Lab}(21 \mathrm{~d})$ & $5 \mathrm{tha}^{-1}$ & 22,600 \\
\hline \multicolumn{7}{|c|}{ B. Agro-Food By-Products and Wastes Used as Soil Amendments of Biological Origin } \\
\hline \multirow{12}{*}{ Lime-based amendments } & \multirow{6}{*}{ Shellfish farming } & \multirow{4}{*}{ Oyster shells (calcined) } & Moon et al. (2013) [80] & Lab (7 d) & (L:S) ratio of 0.2 & 7996 \\
\hline & & & Moon et al. (2013) [83] & $\operatorname{Lab}(28 \mathrm{~d})$ & $3-10 \%(w / w)$ & 11,900 \\
\hline & & & Moon et al. (2016) [84] & $\operatorname{Lab}(28 \mathrm{~d})$ & 0,5, and $10 \%(w / w)$ & 8588 \\
\hline & & & Lee et al. (2013) [85] & $\mathrm{Lab}(28 \mathrm{~d})$ & $5 \%(w / w)$ & 7996 \\
\hline & & Oyster and mussel shells & Ahmad et al. (2012) [82] & $\operatorname{Lab}(1 \mathrm{~d})$ & $2.5,5,10$, and $15 \%$ & 4626 \\
\hline & & Mussel shell & Ahmad et al. (2014) [87] & Lab (175 d) & $5 \%(w / w)$ & 3970 \\
\hline & \multirow{6}{*}{ Poultry industry/farming } & \multirow{3}{*}{ Eggshells (calcined) } & Ahmad et al. (2012) [20] & $\mathrm{Lab}(28 \mathrm{~d})$ & $0,2.5,5,10,15,20,25$, and $30 \%$ & 4626 \\
\hline & & & Almaroai et al. (2014) [22] & $\operatorname{Lab}(21 \mathrm{~d})$ & $5 \%(w / w)$ & 4626 \\
\hline & & & Ahmad et al. (2012) [82] & $\operatorname{Lab}(1 \mathrm{~d})$ & $2.5,5,10$, and $15 \%$ & 4626 \\
\hline & & \multirow{2}{*}{ Poultry waste (incinerated) } & Hashimoto et al. (2008) [27] & $\mathrm{Lab}(15 \mathrm{~d})$ & $3 \%(w / w)$ & 19,600 \\
\hline & & & Hashimoto et al. (2009) [88] & Lab (90 min) & $\mathrm{P} / \mathrm{Pb}$ molar ratio of $3: 5$ & 29,200 \\
\hline & & Poultry litter waste & Hashimoto et al. (2009) [89] & $\operatorname{Lab}(7 \mathrm{~d})$ & $0,0.5,1,3$, and $6 \%(w / w)$ & 18,100 \\
\hline \multirow{4}{*}{ Phosphate amendments } & \multirow{4}{*}{ Livestock activity } & \multirow{4}{*}{ Bone meal or powder } & Almaroai et al. (2014) [22] & $\mathrm{Lab}(21 \mathrm{~d})$ & $5 \%(w / w)$ & 4626 \\
\hline & & & Moon et al. (2013) [83] & $\operatorname{Lab}(28 \mathrm{~d})$ & $3-10 \%(w / w)$ & 11,900 \\
\hline & & & Ahmad et al. (2012) [86] & $\operatorname{Lab}(7 \mathrm{~d})$ & $5 \%(w / w)$ & 11,100 \\
\hline & & & Ahmad et al. (2014) [87] & Lab $(175 \mathrm{~d})$ & $5 \%(w / w)$ & 3970 \\
\hline
\end{tabular}


Table 3. Cont

\begin{tabular}{|c|c|c|c|c|c|c|}
\hline Type of Amendment & Activity & By-Product or Waste & Reference & $\begin{array}{l}\text { Type of Study } \\
\text { (Duration) }\end{array}$ & Treatment Rates & $\begin{array}{l}\text { Range of Soil [Total Pb] * } \\
\left(\mathrm{mg} \mathrm{kg}^{-1}\right)\end{array}$ \\
\hline \multirow{3}{*}{ Phosphate amendments } & \multirow{3}{*}{ Livestock activity } & Bone biochar & Sanderson et al. (2015) [38] & Lab (12 mth) & 1:1 proportion & $399-10,403$ \\
\hline & & $\begin{array}{l}\text { Chicken manure- and green } \\
\text { waste-derived biochars }\end{array}$ & Park et al. (2011) [46] & $\operatorname{Lab}(14 \mathrm{~d})$ & $5 \%(w / w)$ & 346 \\
\hline & & $\begin{array}{l}\text { Dairy manure biomass derived } \\
\text { biochar }\end{array}$ & Cao et al. (2011) [90] & $\operatorname{Lab}(210 \mathrm{~d})$ & 2.5 and $5 \%(w / w)$ & 70,000 \\
\hline \multirow{10}{*}{ Carbon-rich amendments } & Livestock activity & Broiler litter biochars & Uchimiya et al. (2012) [91] & $\operatorname{Lab}(7 \mathrm{~d})$ & $0,2,5,10$, and $20 \%(w / w)$ & 19,906 \\
\hline & \multirow{9}{*}{ Agroforestry } & $\begin{array}{l}\text { Buffalo weed (Ambrosia trifida L.) } \\
\text { biomass derived biochar }\end{array}$ & Rajapaksha et al. (2015) [24] & Lab (12 mth) & $5 \%(w / w)$ & 17,468 \\
\hline & & $\begin{array}{l}\text { Charcoal mixed with compost } \\
\text { made with sewage sludge, freshly } \\
\text { chopped lop, grass and leaves, } \\
\text { and soil and coarse wood } \\
\text { branches }\end{array}$ & Lee et al. (2011) [92] & $\mathrm{Lab}(30 \mathrm{~d})$ & $0,1,3,5,10,20$, and $30 \%$ & 4626 \\
\hline & & & Almaroai et al. (2014) [22] & $\operatorname{Lab}(21 \mathrm{~d})$ & $5 \%(w / w)$ & 4626 \\
\hline & & Oak wood biochar & Ahmad et al. (2012) [86] & $\mathrm{Lab}(7 \mathrm{~d})$ & $5 \%(w / w)$ & 11,100 \\
\hline & & & Ahmad et al. (2014) [87] & Lab (175 d) & $5 \%(w / w)$ & 3970 \\
\hline & & $\begin{array}{c}\text { Soybean stover and pine needles } \\
\text { derived biochars }\end{array}$ & Ahmad et al. (2016) [94] & $\mathrm{Lab}(90 \mathrm{~d})$ & $10 \%(w / w)$ & 17,468 \\
\hline & & $\begin{array}{l}\text { Soybean stover, peanut (Arachis } \\
\text { hypogaea) shell, and pine needle } \\
\text { derived biochars }\end{array}$ & Ahmad et al. (2017) [95] & $\mathrm{Lab}(24 \mathrm{~h})$ & $10 \%(w / w)$ & 17,468 \\
\hline & & $\begin{array}{c}\text { Soybean (Glycine max) stover } \\
\text { derived biochar }\end{array}$ & Vithanage et al. (2017) [96] & Lab (1 mth) & $0,0.5,1$, and $2.5 \%$ & 17,467 \\
\hline & & $\begin{array}{l}\text { Shredded timber waste derived } \\
\text { biochar }\end{array}$ & Silvani et al. (2019) [97] & $\mathrm{Lab}(14 \mathrm{~d})$ & $0,5,10$, and $20 \%$ & $4300-6600$ \\
\hline
\end{tabular}

* Range of soil total $\mathrm{Pb}$ concentration $\left(\mathrm{mg} \mathrm{kg}^{-1}\right) \mathrm{min}$-max averages. 
The selection of the most appropriate immobilizing amendment is critical for the intended remediation technique to be cost-effective and environmentally sound [62,98]. In the following sections, some of the aforementioned inorganic and organic amendments are discussed in detail in relation to their potential for the remediation of $\mathrm{Pb}$-contaminated shooting range soils.

\section{Industrial By-Products and Wastes as Inorganic Soil Amendments}

The disposal of industrial by-products is facing increasing challenges derived from the high costs of operating landfills, in combination with the scarcity of landfill sites and the well-known potential risks of contamination linked to these sites. Alternatively, some industrial by-products, such as fly ash and red mud, can be used as soil amendments, thus offering a sustainable way for the management of contaminated areas in compliance with the EU Waste Framework Directive (Directive 2008/98/EC) [52] and its generic End-of-Waste (EoW) criteria.

Coal fly ash (CFA), also known as pulverized fuel ash, is the major solid by-product generated from coal burning in thermal power stations [62]. The total amount of fuel ash produced worldwide is enormous, in the region of 750 million tonnes per year [99]. Although CFA is one of the cheapest and most widely available waste materials suitable for the reclamation of degraded soils [99,100], the global average utilization rate of CFA is estimated to be less than $25 \%$ [101-103].

Coal fly ash is an alkaline material that is composed mainly of ferroaluminosilicates, with high adsorption capacity $[104,105]$. Numerous studies have documented the potential of CFAs to (i) increase the surface area available for cation adsorption; (ii) improve soil physical properties; (iii) neutralize the $\mathrm{pH}$ of acidic soils; (iv) render cationic metals less mobile; (iv) enhance soil productivity, as they contain alkali $\left(\mathrm{K}^{+}\right)$and alkaline earth metals $\left(\mathrm{Ca}^{2+}, \mathrm{Mg}^{2+}\right)$, which are essential plant nutrients [99, and references therein,105]. The application of CFA as a soil ameliorant has great potential for $\mathrm{Pb}$ immobilization in acidic soils [62]. The $\mathrm{pH}$ of acidic soils usually needs to be increased to alleviate metal-induced toxic effects on plants and soil biota. Although limestone, composed mainly of $\mathrm{CaCO}_{3}$ and / or $\mathrm{CaMg}\left(\mathrm{CO}_{3}\right)_{2}$, has been commonly used as an amendment to increase soil $\mathrm{pH}$, many CFAs, especially those containing alkalizing agents (e.g., $\mathrm{CaO}$ and $\mathrm{Ca}(\mathrm{OH})_{2}$ ), also have the potential to rectify soil acidity problems, while supplying vital plant nutrients [99]. In addition, the use of CFA instead of limestone can reduce $\mathrm{CO}_{2}$ emissions (via surface adsorption and carbonation reaction), with concomitant beneficial effects in terms of mitigating climate change [103].

Although the effectiveness of CFA as a metal-immobilizing agent in soil has been demonstrated [103,106-108], few studies have actually used this material in Pb-contaminated soils and still fewer have used it for the remediation of shooting range soils. Moon et al. (2013) [80] reported that the combination of calcined oyster shells and CFA was a cost-effective treatment for $\mathrm{Pb}$ immobilization in contaminated military firing range soil. Dermatas and Meng (2003) [109] demonstrated that the addition of quicklime and CFA to $\mathrm{Pb} / \mathrm{Cr}$ artificially contaminated soils effectively reduced $\mathrm{Pb}$ leachability below the non-hazardous regulatory limit. Ciccu et al. (2003) [110] and Moon and Dermatas (2006; 2007) [111,112] observed that a relatively small addition of CFA resulted in a significant decrease in the amount of $\mathrm{Pb}$ leached from contaminated soils. A greenhouse experiment found that the application of CFA significantly reduced soluble and exchangeable $\mathrm{Pb}(14.7 \%)$ in contaminated soil, leading to a significant reduction of $\mathrm{Pb}$ in rapeseed plant tissue (66.1\%) [62,113]. Similarly, Kumpiene et al. (2007) [105] observed that the application of CFA and peat to a $\mathrm{Cu} / \mathrm{Pb}$-contaminated soil reduced $\mathrm{Pb}$ leaching by $97 \%$ during a two-year field observation period, which allowed for an increased seed germination rate, reduced metal accumulation in plant shoots, and decreased toxicity to plants and bacteria.

In summary, CFA is a feasible amendment to reduce $\mathrm{Pb}$ toxicity and improve the physico-chemical and biological properties of shooting range soils. There are, nonetheless, factors that restrict CFA application in agricultural and natural soils, such as the presence 
of potentially toxic metalloids and metals (e.g., As, Se, and Cd), high salinity and capacity to reduce the solubility of some essential nutrients [114].

Red mud (also called bauxite residue) is an alkaline solid by-product generated during alumina extraction from bauxite in refineries [115-117]. As a result of the high demand for aluminum, the global inventory of red mud has reached an estimated 4 billion tons, based on its current rate of production, and is still rapidly increasing [117-120]. Currently, red mud is treated as a waste product and is stored in large lagoons or landbased disposal areas [121], which require continuous maintenance. However, its abundance has stimulated extensive research into possible uses [122,123], including its use as a soil amendment for the remediation of soils characterized by high levels of metal(loid)s and low $\mathrm{pH}$ values $[116,124]$.

In general, regardless of the specific production process, red mud contains six major constituents, namely $\mathrm{Fe}_{2} \mathrm{O}_{3}$ (about 20-40\% by mass), $\mathrm{A}_{2} \mathrm{O}_{3}, \mathrm{SiO}_{2}, \mathrm{TiO}_{2}, \mathrm{Na}_{2} \mathrm{O}$ and $\mathrm{CaO}$ [125-128], as well as an array of minor elements, including $\mathrm{Cr}, \mathrm{Cu}, \mathrm{Pb}$, and $\mathrm{Zn}[125,127,128]$. Since red mud itself contains variable amounts of metal(loid)s and high $\mathrm{pH}$ and alkalinity, these characteristics should be carefully considered before reusing red mud for the remediation of contaminated soils $[117,129]$.

Red mud exhibits a greater sorption capacity of $\mathrm{Pb}$ and other metals than fly ash, probably because it contains larger amounts of Fe- and Al-oxides and hydroxides, a larger surface area and pH stabilization ability [130]. Sanderson et al. $(2014 ; 2015)[38,47]$ applied red mud at a rate of $2 \%$ in four shooting ranges and observed a substantial reduction in exchangeable $\mathrm{Pb}$. Several studies have also shown that red mud can reduce metal bioavailability and thus plant metal uptake and accumulation, while enhancing soil microbial biomass and activity and increasing plant biomass production ([123], and references therein). Nonetheless, Sanderson et al. (2014) [47] reported that red-mudamended soils can be toxic to plants and earthworms, probably due to the resulting highly alkaline soil ( $\mathrm{pH}$ 9-12). The high alkaline $\mathrm{pH}$ of red mud can be neutralized through its treatment with seawater, gypsum, etc. [129]. Tandy et al. (2017) [131] demonstrated that the lower $\mathrm{pH}$ of neutralized red mud made it more suitable for plant growth and led to lower values of dissolved organic carbon, thereby preventing loss of soil organic matter and, hence, retaining soil fertility and structure.

Despite their abovementioned benefits for the remediation of shooting range soils, the use of industrial by-products is currently limited, mainly due to high transportation costs, the need for prior processing and/or pretreatment, and data scarcity on their potential environmental impacts [132]. Another practical limitation is the lack of specific guidance or legislation regarding the application of fly ash [133] and red mud [116] in relation to their use for contaminated soil remediation.

\section{Agro-Food By-Products and Wastes as Soil Amendments of Biological Origin}

With the increasing global demand for food production, agricultural and food industries must deal with extremely large amounts of organic waste generated along the food supply chain (production, processing and consumption) [134-136]. Food waste is defined as "fractions of both edible and inedible parts of food removed from the food supply chain" [134]. Current estimates for the EU show that 75-100 million tons of food waste is produced along the food supply chain, which amounts to an average of about $170 \mathrm{~kg}$ per capita per year [134,137]. At present, the majority of food waste is treated as general waste and is therefore sent to landfill or incineration [136,138].

The food waste produced by the agro-food industry, in addition to being a great loss of valuable material, also raises serious problems both from an economic and environmental point of view [136,139]. In this respect, food waste emits over $20 \%$ of the total global production of greenhouse gases, such as methane $\left(\mathrm{CH}_{4}\right)$, nitrous oxide $\left(\mathrm{N}_{2} \mathrm{O}\right)$, and carbon dioxide $\left(\mathrm{CO}_{2}\right)[136,140,141]$. Additionally, food waste leachates from landfills constitute a high potential risk for contamination of surface waters and groundwater [23]. As a result of the incineration of food waste, emissions to air of particulate matter (especially 
dust), acid gases ( $\left.\mathrm{HCl}, \mathrm{HF}, \mathrm{SO}_{2}{ }^{-}, \mathrm{CO}, \mathrm{NO}_{\mathrm{x}}\right)$, dioxins and VOCs [142,143] are produced, with concomitant negative impacts on human and ecosystem health. On the other hand, incineration often involves high energy consumption [136,144,145].

Food waste must be urgently reduced and diverted from disposal in landfills, as advocated by the Integrated Product Policy (IPP) [146], the Roadmap to a Resource Efficient Europe [147], now embodied in the Resource Efficiency Flagship of the Europe 2020 Strategy [148], the Bioeconomy Strategy [149], Target 12.3 of the UN Sustainable Development Goals (which aims at halving wastage by 2030), and the European Green Deal Strategy [56]. The agro-food sector is particularly committed to adopting strategies and challenges within circular economy principles, and therefore, actions are being taken towards the valorization and recycling of food waste, with a view to transforming it into a valuable resource. Food waste can be valorized into a range of high-value-added products, including biofertilizers and soil amendments, to, for instance, reverse land degradation in agricultural areas and assist in the remediation of contaminated soils [136]. For acidic and clayey soils in shooting ranges close to forested areas, the US EPA (2005) [5] traditionally recommends the application of lime-based amendments. However, limestone mining can be a destructive process, with cascading environmental impacts [150]. As a more sustainable alternative, biogenic carbonate materials, such as treated oyster and mussel shells and eggshells, are also being used for metal removal and immobilization in shooting range soils (Table 3B). The disposal and utilization of products of animal origin and animal by-products in soils not intended for agricultural use is regulated by Commission Regulation (EU) No. 142/2011, which sets out methods for disposal or use defined by Regulation (EC) No. 1069/2009 in order to minimize potential risk to public and animal health as well as to avoid any threat of pathogens and disease dispersion [151].

Shellfish farming is an expanding economic activity worldwide and generates a large volume of waste, including an abundance of mollusk shells [152]. In China, the largest producer of shellfish in the world, about 10 million tons of waste seashells are disposed of in landfills annually [153]. Seashell waste, which includes oyster and mussel shells, is particularly rich in calcite $\left(\mathrm{CaCO}_{3}\right)$ and quicklime $(\mathrm{CaO})$ components, which might form insoluble metal hydroxides at alkaline $\mathrm{pH}$ values [154-156]. To convert the relatively less reactive $\mathrm{CaCO}_{3}$ into highly reactive $\mathrm{CaO}$, a calcination process is usually adopted. Moon et al. $[80,83]$ stabilized $\mathrm{Pb}$ and $\mathrm{Cu}$ in a shooting range soil located in Busan Metropolitan City (Korea) using calcined oyster shells mixed with bone meal or fly ash as amendments. These authors tested the effectiveness of the stabilization process according to the Toxicity Characteristic Leaching Procedure using the $0.1 \mathrm{M} \mathrm{HCl}$ extraction method and observed a drastic reduction of $\mathrm{Pb}(98 \%)$ and $\mathrm{Cu}(96 \%)$ leaching when soils were treated with calcined oyster shell, whether it was mixed with bone meal ( $5 \%$ each on a weight basis) or with fly ash (10\% and $5 \%$, respectively). From the results of their batch- and column-leaching tests, Lee et al. (2013) [85] concluded that the application of calcined oyster shell waste, together with coal mine drainage sludge, was an effective treatment for the simultaneous immobilization of $\mathrm{As}, \mathrm{Pb}$ and $\mathrm{Cu}$ in soils from a Korean military shooting range. In a similar study, scanning electron microscopy-energy dispersive X-ray spectroscopy analyses performed by Moon et al. (2016) [84] indicated that As immobilization may be associated with the formation of Ca-As and Fe-As precipitates, while $\mathrm{Pb}$ and $\mathrm{Cu}$ immobilization was most probably linked to calcium silicate hydrates and calcium aluminum hydrates.

Oyster shells, mussel shells and eggshells were assessed by Ahmad et al. (2012) [82] for their effectiveness towards $\mathrm{Pb}$ and $\mathrm{Cu}$ immobilization in highly contaminated shooting range soil. The rise in soil $\mathrm{pH}$ due to amendment application resulted in the formation of relatively insoluble Pb-hydroxide. However, all lime-based waste materials failed to immobilize $\mathrm{Cu}$. This is not surprising, since it is a well-known fact that soil composition can significantly affect the performance of these amendments.

Eggshell is also one of the most important food wastes, with an annual worldwide production of ca. 250,000 tons [157]. Eggshell is an alkaline and nitrogen rich material with 
a high content of $\mathrm{CaCO}_{3}(>90 \%)$, embedded in an organic framework of protein fibers [151]. Ahmad et al. (2012) [86] investigated $\mathrm{Pb}$ immobilization in shooting range soil amended with raw and calcined eggshell waste. Both amendments decreased the exchangeable $\mathrm{Pb}$ fraction to $1 \%$ of the total soil $\mathrm{Pb}$ content $\left(>4600 \mathrm{mg} \mathrm{kg}^{-1}\right)$, while the carbonate-associated $\mathrm{Pb}$ fraction was increased to $40.0-47.1 \%$ at $>15 \%$ application rates. These authors proposed that their eggshell amendment was immobilizing soil $\mathrm{Pb}$ via the formation of $\mathrm{Pb}(\mathrm{OH})_{2}$ or $\mathrm{Pb}_{2} \mathrm{O}\left(\mathrm{SO}_{4}\right)$, adsorption on Al-containing minerals, and co-precipitation as carbonate. In turn, $\mathrm{Pb}$ in soil amended with calcined eggshell was associated with $\mathrm{Si}$ and $\mathrm{Ca}^{2+}$ and then possibly immobilized by entrapping into calcium-silicate-hydrate [86].

Among the best management practices to prevent soil $\mathrm{Pb}$ migration, phosphate application, alone or in conjunction with lime, is recommended by the US EPA. Immobilization of $\mathrm{Pb}$ with phosphates in contaminated soils relies on the formation of the highly insoluble mineral pyromorphite $\left[\mathrm{Pb}_{5}\left(\mathrm{PO}_{4}\right)_{3} X\right.$, where $\left.X=\mathrm{Cl}^{-}, \mathrm{OH}^{-}, \mathrm{F}^{-}\right]$[158]. Given the relatively high cost of phosphate treatments, bone meal (calcium phosphate) can also be considered as a readily available phosphate source for the remediation of $\mathrm{Pb}$-contaminated soils [159]. In fact, the bioavailable fraction of $\mathrm{Pb}$ in shooting range soils can be reduced effectively by the addition of bone meal as an amendment, thereby decreasing the risk of ecotoxicity [20,22,83]. Ahmad et al. (2014) [87] reported that stable Pb species, such as $\mathrm{Pb}$-hydroxide, $\mathrm{Pb}$ sorbed on kaolinite and chloropyromorphite, were formed in shooting range soils amended with mussel shells, biochar and bone meal, respectively.

Over the last years, one of the most promising options for achieving the so-called "zero-waste-to-landfill" goal in agriculture and forestry is to convert wastes into biochars. The term biochar refers to a porous carbonaceous solid produced by thermochemical conversion of organic materials in the absence of oxygen [160]. Biochar is commonly produced from pyrolysis of animal manures, crop residues, grasses and weeds, wood biomass, sewage sludge and municipal solid waste at a temperature ranging from 200 to $800{ }^{\circ} \mathrm{C}[161,162]$. The unique physico-chemical and sorptive properties of biochar, such as large surface area, high porosity, dominance of negatively charged surface functional groups, high cation exchange capacity and long-term stability [163], make it highly recommended as an amendment for contaminated soils. Biochar amendments can immobilize positive $\mathrm{Pb}$ cations through electrostatic attraction, precipitation as $\mathrm{Pb}$-phosphate, surface complexation, and increasing soil $\mathrm{pH}[24,87,90,94,95]$. Nonetheless, the effectiveness of biochar for metal immobilization is heavily determined by the source of biomass feedstock and the specific pyrolysis conditions $[19,164,165]$.

A number of studies have examined the suitability of biochars for metal immobilization in shooting range soils, as summarized in Table 3B. In most of these studies, short-term batch experiments were conducted using biochars derived from manures [46,90], crop residues $[24,85,93-97]$ and oak wood $[20,22,87]$. In most cases, biochar proved to be a versatile functional material, not only because it promoted soil $\mathrm{Pb}$ immobilization, but also because its application led to the incorporation (and retention) of labile organic carbon and nutrients, which in turn improved soil fertility and enhanced plant growth and soil microbial activity $[166,167]$. Even though the majority of studies showed the beneficial effects of biochar, the lack of field-scale studies [168], scarce ecotoxicological data $[169,170]$ and legal restrictions [171] still limit its application in soil amendment.

The selection of the most appropriate amendment among those described in Sections 3 and 4 for the in situ remediation of a specific shooting range soil is a complex but essential task. When selecting industrial or agro-food by-products (or other wastes) as soil amendments, the following aspects should be simultaneously taken into consideration: (i) site-specific edaphoclimatic conditions, including both soil physicochemical and biological properties; (ii) contamination type and the extension of the affected area; (iii) the production rate and availability of the by-product or waste as well as the availability of space for its proper storage; (iv) physical characteristics and chemical composition of the by-product or waste as well as potential the environmental risks associated with high conductivity (salinity) and/or very high/low $\mathrm{pH}$ values; (v) cost of the transformation processes required 
prior to amendment application as well as transport costs; (vi) available information on application procedures and the effectiveness for metal $(\mathrm{Pb})$ immobilization, obtained from both microcosm and field experiments; (vii) public acceptance regarding the use of industrial and agro-food by-products as soil amendments.

\section{Effectiveness of Agro-Industrial Wastes as Amendments for the Remediation of Pb-Contaminated Shooting Range Soil: A Practical Example from Basque Country (Spain)}

In Spain, where it is estimated that hunting and shooting are responsible for the dispersion in nature of about 6000 tonnes of $\mathrm{Pb}$ per year [172,173], there are over 770 shooting ranges $[10,174]$. According to a local hunting foundation [175], hunting is practiced by $1.6 \%$ of the population of the Basque Country (northern Spain). In many cases, recreational shooting ranges are located in meadows nearby forest plots and close to farm houses and/or agricultural lands, making these environments vulnerable to $\mathrm{Pb}$ contamination. Since shooting has been classified as a potentially contaminating activity by Spanish legislation (Spanish Royal Decree (RD) 9/2005), several initiatives are being conducted to remediate shooting range soils impacted by $\mathrm{Pb}$ contamination $[10,42,174]$.

Phytomanagement practices have positioned themselves as cost-effective technologies for the sustainable long-term remediation of large areas affected by mild to medium levels of soil contamination [176-180]. Phytomanagement usually involves the cultivation of profitable plants (mainly non-food crops) in organically amended soils to control the bioavailable fraction of contaminants, thereby minimizing environmental risks while maximizing ecological, social and economic revenues [70,176,179]. It is necessary to conduct preliminary research to gather data on the effectiveness of the available amendments for metal immobilization before their use for on-site phytomanagement.

The main objective of the practical experience detailed below was to evaluate the effectiveness of three different agro-industrial wastes for soil $\mathrm{Pb}$ immobilization at a shooting range situated in the municipality of Oiartzun (Basque Country, Spain). Specifically, we compared the effect of the application of spent mushroom substrate (SMS), forest wood-derived biochar (BC) and bone meal (BM) on the $\mathrm{CaCl}_{2}$-extractable $\mathrm{Pb}$ fraction under laboratory and field conditions. A detailed description of materials and methods for this practical experience can be found in the Supplementary Materials. Briefly, a microcosm experiment was carried out using topsoil $(0-20 \mathrm{~cm})$ with a total $\mathrm{Pb}$ concentration of $2058 \mathrm{mg} \mathrm{kg}^{-1} \mathrm{DW}$ soil. This Pb concentration was approximately 17 times higher than the Critical Reference Concentration established by Basque legislation [181] and 7 times higher than the maximum allowable concentration for agricultural settings set by European legislation [17]. The $\mathrm{CaCl}_{2}$-extractable $\mathrm{Pb}$ concentration of soil samples from this shooting range was approximately $12 \mathrm{mg} \mathrm{kg}^{-1} \mathrm{DW}$ soil, accounting for $0.6 \%$ of the total $\mathrm{Pb}$ concentration. This shooting range soil, therefore, was severely contaminated with $\mathrm{Pb}$ and required the implementation of an effective remediation strategy. To this end, first, a microcosm experiment was conducted in order to evaluate the effectiveness of three agro-industrial wastes (SMS, BC and BM: $5 \% w / w$ ) under controlled laboratory conditions. A control treatment (without amendment) was also studied. Four independent pots for each treatment were arranged. Lead immobilization was evaluated in terms of the reduction of $\mathrm{CaCl}_{2}$-extractable $\mathrm{Pb}$. Blank samples were included in all the analyses to verify any possible cross-contamination. Soil $\mathrm{pH}$ was also measured. Following the microcosm experiment, a field experiment was established in the shooting range. Biochar and BM $(5 \%$ $w / w)$ were applied as soil amendments in three independent plots. An unamended control treatment was also included in this on-site experiment. Soil samples from each plot were collected at 0, 7 and 17 days after amendment application to determine soil extractable $\mathrm{Pb}$ and $\mathrm{pH}$.

In the microcosm study, immediately after their application, BC and BM amendments significantly $(p<0.05)$ decreased extractable $\mathrm{Pb}$ concentrations compared to the control and SMS-amended soils (Figure 1). The addition of BC and BM to the shooting range soil caused a pronounced reduction (90 and 95\%, respectively) of extractable $\mathrm{Pb}$ compared 
to the control treatment. This effect remained for up to 7 days for BC and BM. For less effective treatments (C, SMS), a significant increase in extractable $\mathrm{Pb}$ concentration was observed at this time. Under our experimental conditions, treated soils had a short aging period (7 days). Other abiotic factors (redox reactions, interactions with soil components, etc.) and/or the activity of soil microorganisms could be responsible for the observed increase in extractable $\mathrm{Pb}$ levels.

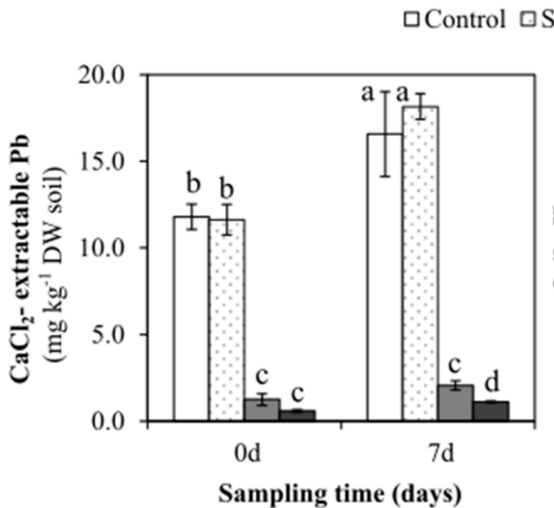

(a)

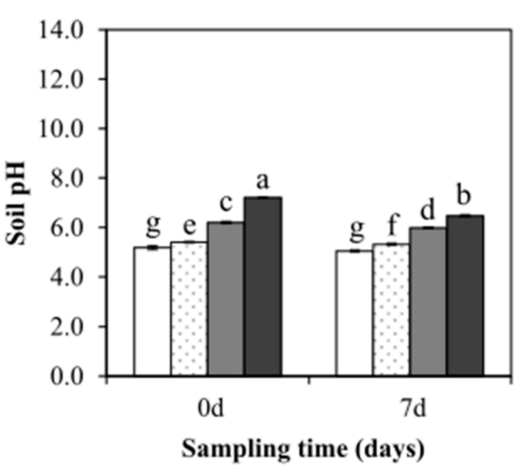

(b)

Figure 1. (a) $\mathrm{CaCl}_{2}$-extractable $\mathrm{Pb}$ concentrations and (b) $\mathrm{pH}$ of control soil and SMS-, BC- and $\mathrm{BM}$-amended soils at 0 and 7 days after amendment application. Error bars represent standard errors. Different lower case letters above error bars indicate significant differences at $p<0.05$ among means of different treatments.

In addition to the effective interaction of $\mathrm{Pb}$ with specific chemical components of $\mathrm{BC}$ and $\mathrm{BM}$ amendments (see Section 4 and reviews $[9,19,28]$ ), the higher $\mathrm{pH}$ values reported in BC- and BM-amended soils ( $\mathrm{pH} 6.2$ and 7.2, respectively) in comparison with control soils ( $\mathrm{pH}$ 5.2) (Figure $1 \mathrm{~b}$ ) could also contribute to the reduction in extractable $\mathrm{Pb}$ concentrations. In fact, a statistically significant negative correlation between extractable $\mathrm{Pb}$ in amended soils and $\mathrm{pH}(0 \mathrm{~d}: \rho=-0.853 ; 7 \mathrm{~d}: \rho=-0.778$, both $p<0.05)$ was observed. The induction of soil alkalinization by the application of amendments is an alternative for promoting soil $\mathrm{Pb}$ immobilization, as previously pointed out by Ahmad et al. (2012; 2014) [20,87]. The addition of SMS to soil under our experimental conditions, however, did not alter extractable $\mathrm{Pb}$ concentrations.

Our field experiment confirmed the above-mentioned effectiveness of BC and BM amendments by significantly reducing soil extractable $\mathrm{Pb}$ concentrations (Figure 2a). In the amended soil, $\mathrm{Pb}$ remained immobilized, even 17 days after the application of the amendments. Our findings indicate that a 5\% BC and BM application rate is appropriate for $\mathrm{Pb}$ immobilization in shooting range soil. When measuring soil microbial activity, BM-amended soils exhibited higher values of $\mathrm{CO}_{2}$ per unit biomass and time $\left(\approx 18 \mu \mathrm{g} \mathrm{CO}{ }_{2}-\mathrm{C} \mathrm{g}^{-1}\right.$ soil h$\left.^{-1}\right)$ than control and BC-amended soils $\left(\approx 2 \mu \mathrm{g} \mathrm{CO} \mathrm{CO}_{2}-\mathrm{C} \mathrm{g}^{-1}\right.$ soil h$\left.^{-1}\right)$. This higher $\mathrm{CO}_{2}$ production could be due to decarbonation processes.

Our findings are in good agreement with previous studies by Ahmad et al. (2012; 2014) $[20,87]$, which related metal retention onto soil particles (via metal phosphate formation, adsorption/complexation and ion exchange) with an increase of $\mathrm{pH}$ in shooting range soils treated with $5 \% \mathrm{BC}$ and $\mathrm{BM}$. The high efficiency of both $\mathrm{BC}$ and $\mathrm{BM}$ for soil $\mathrm{Pb}$ immobilization may be attributed to the adsorption of $\mathrm{Pb}$ [46] and precipitation of $\mathrm{Pb}$ phosphate [159], respectively. The immobilization of $\mathrm{Pb}$ after the incorporation of biochar to soil has been associated with elevated concentrations of soluble carbon [46] (Table S1, Supplementary Materials), its high-sorption properties due to its relatively high-specific surface area (porous structure) [22], and the abundance of carboxyl functional groups [91]. The BM is usually characterized by a high content of Ca-bearing minerals and $\mathrm{P}$ in the 
form of $\mathrm{P}_{2} \mathrm{O}_{5}$ [87] (Table S1). These components may have contributed to the formation of geochemically stable $\mathrm{Pb}$ species, leading to a lower leachability [83].

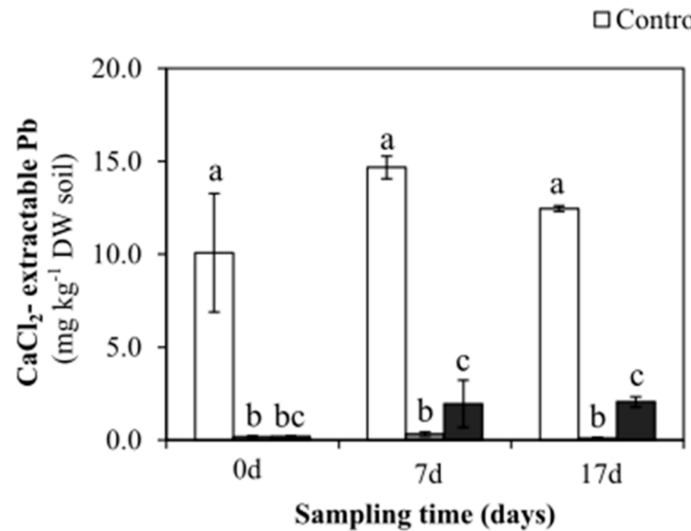

(a)

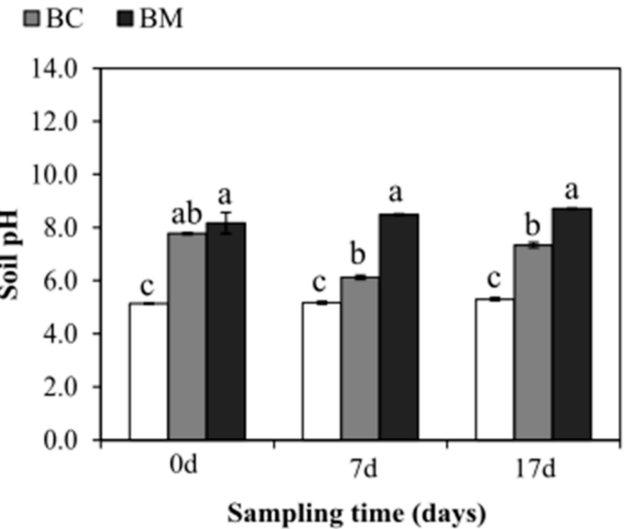

(b)

Figure 2. (a) $\mathrm{CaCl}_{2}$-extractable $\mathrm{Pb}$ concentrations and (b) $\mathrm{pH}$ of control soil and $\mathrm{BC}$ - and $\mathrm{BM}$-amended soils at 0,7 and 17 days after amendment application, under field conditions. Error bars represent standard errors. Different lower case letters above error bars indicate significant differences at $p<0.05$ among means of different treatments.

In view of the high $\mathrm{Pb}$ immobilization capacity of $\mathrm{BC}$ and $\mathrm{BM}$, we concluded that these wastes are suitable amendments for the phytomanagement of soils affected by shooting activity. The immobilization effect of amendments can be initially assessed with a simple and cheap approach at a microcosm scale in the laboratory. The presented practical experience under field conditions shows the immediate ( 0 days) and short-term ( 7 days, 17 days) effects of amendment application on $\mathrm{Pb}$ extractability in shooting range soil. Nonetheless, further on-site studies are required to determine the longer term effects of these soil amendments, not only on $\mathrm{Pb}$ immobilization but also on soil health.

\section{Concluding Remarks}

Shooting ranges have been identified as sources of $\mathrm{Pb}$ contamination. Chemical immobilization, through the use of inorganic and organic soil amendments, is one of the most effective strategies for reducing $\mathrm{Pb}$ extractability and bioavailability and, hence, ecotoxicity. Amendments from agro-food and industrial by-products and wastes have great potential for soil remediation purposes. The practical experience presented here opens the door to the application of forest wood biochar and bone meal for the remediation of shooting range soils, thus fostering the implementation of circular economy principles for a sustainable waste management. Despite increasing research on the application of soil amendments to immobilize soil $\mathrm{Pb}$, there are still some aspects that need to be developed. For instance, ongoing research is mostly focused on short-term laboratory experiments or leaching tests. Results from these studies should be verified by field studies. Field-scale studies not only allow researchers to confirm the effectiveness of by-products and wastes as metal immobilizing agents, but also to optimize their application rate and assess the effect of site-specific edaphoclimatic conditions on extractable metal concentrations. It is also important to investigate how these amendments can interact with other co-contaminants of shooting ranges, such as $\mathrm{Sb}$, as well as their long-term effects on soil biota and vegetation. Finally, remediation studies of shooting range soils should address, when possible, the links and trade-offs between environmental and socio-economic gains.

Supplementary Materials: The following are available online at https: / www.mdpi.com/article / 10.3390/pr9040572/s1, detailed description of materials and methods for Section 5 and Table S1: Physico-chemical characteristics of spent mushroom substrate (SMS), biochar (BC) and animal bone meal (BM) on a dry weight basis. 
Author Contributions: M.T.G.-S., C.G. and J.M.B. contributed in a significant way to the conception of the study, experimental design and coordination of the work. M.T.G.-S. had the major role in writing up the final draft of the paper and in the experimental procedures. M.A., J.H. and U.A. participated in soil preparation and soil sample collection and processing. C.G. and J.M.B. were responsible for funding acquisition. All the authors took part in the editing of the manuscript. All authors have read and agreed to the published version of the manuscript.

Funding: This work was financially supported by PRADA project (PID2019-110055RB-C21 and PID2019-110055RB-C22) from MINECO, Phy2SUDOE project (SOE4/P5/E1021) funded by the Interreg Sudoe Programme through the European Regional Development Fund (ERDF), Consolidated Research Group of the Basque Government (GV ITO18-16) and, finally, OTRI project 2020.0670.

Institutional Review Board Statement: We have not included an IRB statement, as IRB approval is not required for the review and research presented in this paper.

Informed Consent Statement: We have not included an IC statement, as no data collected on humans were used for the review and research presented in this document.

Data Availability Statement: No datasets were analyzed or generated during the present work.

Acknowledgments: The authors would like to acknowledge the collaboration of Juan Carlos Raposo from SGIker Service of the UPV/EHU. We are also grateful to Antonio Bea from EKOS Environmental Studies (Lasarte-Oria) for providing access to the shooting range soil to perform the demonstration study. The authors express their deep gratitude to the editors and anonymous reviewers for their valuable comments and suggestions.

Conflicts of Interest: The authors declare no competing financial interests or personal relationships that could have appeared to influence the work reported in this paper.

\section{References}

1. Stansley, W.; Roscoe, D.E. The uptake and effects of lead in small mammals and frogs at a trap and skeet range. Arch. Environ. Contam. Toxicol. 1996, 30, 220-226. [CrossRef]

2. Rooney, C.P.; Mclaren, R.G.; Cresswell, R.J. Distribution and phytoavailability of lead in a soil contaminated with lead shot. Water Air Soil Pollut. 1999, 116, 535-548. [CrossRef]

3. Migliorini, M.; Pigino, G.; Bianchi, N.; Bernini, F.; Leonzio, C. The effects of heavy metal contamination on the soil arthropod community of a shooting range. Environ. Pollut. 2004, 129, 331-340. [CrossRef] [PubMed]

4. Sorvari, J.; Antikainen, R.; Pyy, O. Environmental contamination at Finnish shooting ranges-the scope of the problem and management options. Sci. Total Environ. 2006, 366, 21-31. [CrossRef]

5. U.S. Environmental Protection Agency (US-EPA). Best Management Practices for Lead at Outdoor Shooting Ranges; U.S. Environmental Protection Agency/Division of Enforcement and Compliance Assistance: New York, NY, USA, 2005; p. 103.

6. Tranel, M.A.; Kimmel, R.O. Impacts of Lead Ammunition on Wildlife, the Environment, and Human Health-A Literature Review and Implications for Minnesota. In Ingestion of Lead from Spent Ammunition: Implications for Wildife and Humans; Watson, M.P.R.T., Fuller, M., Hunt, W.G., Eds.; The Peregrine Fund: Boise, ID, USA, 2009; pp. 318-337. [CrossRef]

7. Perroy, R.L.; Belby, C.S.; Mertens, C.J. Mapping and modeling three dimensional lead contamination in the wetland sediments of a former trap-shooting range. Sci. Total Environ. 2014, 487, 72-81. [CrossRef] [PubMed]

8. Yin, X.; Saha, U.K.; Ma, L.Q. Effectiveness of best management practices in reducing Pb-bullet weathering in a shooting range in Florida. J. Hazard. Mater. 2010, 179, 895-900. [CrossRef] [PubMed]

9. Ahmad, M.; Lee, S.S.; Moon, D.H.; Yang, J.E.; Ok, Y.S. A Review of Environmental Contamination and Remediation Strategies for Heavy Metals at Shooting Range Soils-Environmental Protection Strategies for Sustainable Development; Malik, A., Grohmann, E., Eds.; Springer: Dordrecht, The Netherlands, 2012; pp. 437-451. ISBN 978-94-007-1591-2.

10. Rodríguez-Seijo, A.; Lago-Vila, M.; Andrade, M.L.; Vega, F.A. Pb pollution in soils from a trap shooting range and the phytoremediation ability of Agrostis capillaris L. Environ. Sci. Pollut. Res. 2016, 23, 1312-1323. [CrossRef]

11. Chrastný, V.; Komárek, M.; Hájek, T. Lead contamination of an agricultural soil in the vicinity of a shooting range. Environ. Monit. Assess. 2010, 162, 37-46. [CrossRef]

12. Lin, Z.; Comet, B.; Qvarfort, U.; Herbert, R. The chemical and mineralogical behaviour of Pb in shooting range soils from central Sweden. Environ. Pollut. 1995, 89, 303-309. [CrossRef]

13. Chen, M.; Daroub, S.H. Characterization of lead in soils of a rifle/pistol shooting range in central Florida, USA. Soil Sediment Contam 2002, 11, 1-17. [CrossRef]

14. Cao, X.; Ma, L.Q.; Chen, M.; Hardison, D.W.; Harris, W.G. Lead transformation and distribution in the soils of shooting ranges in Florida, USA. Sci. Total Environ. 2003, 307, 179-189. [CrossRef]

15. Cao, X.; Ma, L.Q.; Chen, M.; Hardison, D.W.; Harris, W.G. Weathering of lead bullets and their environmental effects at outdoor shooting ranges. J. Environ. Qual. 2003, 1, 526-534. [CrossRef] 
16. Dermatas, D.; Cao, X.; Tsaneva, V.; Shen, G.; Grubb, D.G. Fate and behavior of metal(loid) contaminants in an organic matter-rich shooting range soil: Implications for remediation. Water Air Soil Pollut. Focus 2006, 6, 143-155. [CrossRef]

17. European Commission Council Directive (86/278/EEC), of 12 June 1986, on the protection of the environment, and in particular of the soil, when sewage sludge is used in agriculture. Off. J. Eur. Communities 1986, 4, 6-12.

18. U.S. Environmental Protection Agency (US-EPA). Soil Screening Guidance: User's Guide Second Edition; U.S. Environmental Protection Agency/Office of Solid Waste and Emergency Response: Washington, DC, USA, 1996; p. 49.

19. Sanderson, P.; Qi, F.; Seshadri, B.; Wijayawardena, A.; Naidu, R. Contamination, fate and management of metals in shooting range soils-A review. Curr. Pollut. Rep. 2018, 4, 175-187. [CrossRef]

20. Ahmad, M.; Soo Lee, S.; Yang, J.E.; Ro, H.M.; Han Lee, Y.; Sik Ok, Y. Effects of soil dilution and amendments (mussel shell, cow bone, and biochar) on $\mathrm{Pb}$ availability and phytotoxicity in military shooting range soil. Ecotoxicol. Environ. Saf. 2012, 79, 225-231. [CrossRef] [PubMed]

21. Ahmad, M.; Usman, A.R.A.; Lee, S.S.; Kim, S.C.; Joo, J.H.; Yang, J.E.; Ok, Y.S. Eggshell and coral wastes as low cost sorbents for the removal of $\mathrm{Pb}^{2+}, \mathrm{Cd}^{2+}$ and $\mathrm{Cu}^{2+}$ from aqueous solutions. J. Ind. Eng. Chem. 2012, 18, 198-204. [CrossRef]

22. Almaroai, Y.A.; Usman, A.R.A.; Ahmad, M.; Moon, D.H.; Cho, J.S.; Joo, Y.K.; Jeon, C.; Lee, S.S.; Ok, Y.S. Effects of biochar, cow bone, and eggshell on $\mathrm{Pb}$ availability to maize in contaminated soil irrigated with saline water. Environ. Earth Sci. 2014, 71, 1289-1296. [CrossRef]

23. Bolan, N.; Kunhikrishnan, A.; Thangarajan, R.; Kumpiene, J.; Park, J.; Makino, T.; Kirkham, M.B.; Scheckel, K. Remediation of heavy metal(loid)s contaminated soils-To mobilize or to immobilize? J. Hazard. Mater. 2014, 266, 141-166. [CrossRef]

24. Rajapaksha, A.U.; Ahmad, M.; Vithanage, M.; Kim, K.R.; Chang, J.Y.; Lee, S.S.; Ok, Y.S. The role of biochar, natural iron oxides, and nanomaterials as soil amendments for immobilizing metals in shooting range soil. Environ. Geochem. Health 2015, 37, 931-942. [CrossRef] [PubMed]

25. Brown, S.L.; Henry, C.L.; Chaney, R.; Compton, H.; DeVolder, P.S. Using municipal biosolids in combination with other residuals to restore metal-contaminated mining areas. Plant Soil 2003, 249, 203-215. [CrossRef]

26. Mench, M.; Bussière, S.; Boisson, J.; Castaing, E.; Vangronsveld, J.; Ruttens, A.; De Koe, T.; Bleeker, P.; Assunção, A.; Manceau, A. Progress in remediation and revegetation of the barren Jales gold mine spoil after in situ treatments. Plant Soil 2003, 249, 187-202. [CrossRef]

27. Hashimoto, Y.; Matsufuru, H.; Sato, T. Attenuation of lead leachability in shooting range soils using poultry waste amendments in combination with indigenous plant species. Chemosphere 2008, 73, 643-649. [CrossRef]

28. Sanderson, P.; Naidu, R.; Bolan, N.; Bowman, M. Critical review on chemical stabilization of metal contaminants in shooting range soils. J. Hazard. Toxic Radioact. Waste 2012, 16, 258-272. [CrossRef]

29. Suresh, B.; Ravishankar, G.A. Phytoremediation-A novel and promising approach for environmental clean-up. Crit. Rev. Biotechnol. 2004, 24, 97-124. [CrossRef] [PubMed]

30. Wilde, E.W.; Brigmon, R.L.; Dunn, D.L.; Heitkamp, M.A.; Dagnan, D.C. Phytoextraction of lead from firing range soil by Vetiver grass. Chemosphere 2005, 61, 1451-1457. [CrossRef]

31. Bandara, T.; Vithanage, M. Phytoremediation of shooting range soils. In Phytoremediation: Management of Environmental Contaminants; Ansari, A.A., Gill, S.S., Gill, R., Lanza, G.R., Newman, L., Eds.; Springer International Publishing: Cham, Switzerland, 2016; Volume 3, pp. 1-576. ISBN 9783319401485.

32. Tariq, S.R.; Ashraf, A. Comparative evaluation of phytoremediation of metal contaminated soil of firing range by four different plant species. Arab. J. Chem. 2016, 9, 806-814. [CrossRef]

33. Grison, C. Combining phytoextraction and ecocatalysis: A novel concept for greener chemistry, an opportunity for remediation. Environ. Sci. Pollut. Res. Int. 2015, 22, 5589-5591. [CrossRef] [PubMed]

34. Deyris, P.A.; Grison, C. Nature, ecology and chemistry: An unusual combination for a new green catalysis, ecocatalysis. Curr. Opin. Green Sustain. Chem. 2018, 10, 6-10. [CrossRef]

35. Jiang, Y.; Lei, M.; Duan, L.; Longhurst, P. Integrating phytoremediation with biomass valorisation and critical element recovery: A UK contaminated land perspective. Biomass Bioenergy 2015, 83, 328-339. [CrossRef]

36. Cao, X.; Wahbi, A.; Ma, L.; Li, B.; Yang, Y. Immobilization of $\mathrm{Zn}, \mathrm{Cu}$, and $\mathrm{Pb}$ in contaminated soils using phosphate rock and phosphoric acid. J. Hazard. Mater. 2009, 164, 555-564. [CrossRef]

37. Sanderson, P.; Naidu, R.; Bolan, N.; Lim, J.E.; Ok, Y.S. Chemical stabilisation of lead in shooting range soils with phosphate and magnesium oxide: Synchrotron investigation. J. Hazard. Mater. 2015, 299, 395-403. [CrossRef] [PubMed]

38. Sanderson, P.; Naidu, R.; Bolan, N. Effectiveness of chemical amendments for stabilisation of lead and antimony in risk-based land management of soils of shooting ranges. Environ. Sci. Pollut. Res. 2015, 22, 8942-8956. [CrossRef]

39. Arenas-Lago, D.; Rodríguez-Seijo, A.; Lago-Vila, M.; Couce, L.A.; Vega, F.A. Using $\mathrm{Ca}_{3}\left(\mathrm{PO}_{4}\right)_{2}$ nanoparticles to reduce metal mobility in shooting range soils. Sci. Total Environ. 2016, 571, 1136-1146. [CrossRef]

40. Seshadri, B.; Bolan, N.S.; Choppala, G.; Kunhikrishnan, A.; Sanderson, P.; Wang, H.; Currie, L.D.; Tsang, D.C.W.; Ok, Y.S.; Kim, K. Potential value of phosphate compounds in enhancing immobilization and reducing bioavailability of mixed heavy metal contaminants in shooting range soil. Chemosphere 2017, 184, 197-206. [CrossRef]

41. Fayiga, A.O.; Saha, U.K. Effect of phosphate treatment on Pb leachability in contaminated shooting range soils. Soil Sediment Contam. 2017, 26, 115-126. [CrossRef] 
42. Rodríguez-Seijo, A.; Vega, F.A.; Arenas-Lago, D. Assessment of iron-based and calcium-phosphate nanomaterials for immobilisation of potentially toxic elements in soils from a shooting range berm. J. Environ. Manag. 2020, 267. [CrossRef]

43. Cao, X.; Dermatas, D.; Xu, X.; Shen, G. Lead in shooting range soils Subject Area 2.1: Methodologies of chemicals in soils/sediments Immobilization of lead in shooting range soils by means of cement, quicklime, and phosphate amendments. Environ. Sci. Pollut. Res. 2008, 15, 120-127. [CrossRef] [PubMed]

44. Conesa, H.M.; Wieser, M.; Studer, B.; González-Alcaraz, M.N.; Schulin, R. A critical assessment of soil amendments (slaked lime/acidic fertilizer) for the phytomanagement of moderately contaminated shooting range soils. J. Soils Sediments 2012, 12, 565-575. [CrossRef]

45. Okkenhaug, G.; Grasshorn Gebhardt, K.A.; Amstaetter, K.; Lassen Bue, H.; Herzel, H.; Mariussen, E.; Almås, Å.R.; Cornelissen, G.; Breedveld, G.D.; Rasmussen, G.; et al. Antimony ( $\mathrm{Sb}$ ) and lead $(\mathrm{Pb})$ in contaminated shooting range soils: $\mathrm{Sb}$ and $\mathrm{Pb}$ mobility and immobilization by iron based sorbents, a field study. J. Hazard. Mater. 2016, 307, 336-343. [CrossRef]

46. Park, J.H.; Bolan, N.S.; Chung, J.W.; Naidu, R.; Megharaj, M. Environmental monitoring of the role of phosphate compounds in enhancing immobilization and reducing bioavailability of lead in contaminated soils. J. Environ. Monit. 2011, 13, 2234-2242. [CrossRef]

47. Sanderson, P.; Naidu, R.; Bolan, N. Ecotoxicity of chemically stabilised metal(loid)s in shooting range soils. Ecotoxicol. Environ. Saf. 2014, 100, 201-208. [CrossRef]

48. Sanderson, P.; Naidu, R.; Bolan, N. The effect of environmental conditions and soil physicochemistry on phosphate stabilisation of $\mathrm{Pb}$ in shooting range soils. J. Environ. Manag. 2016, 170, 123-130. [CrossRef] [PubMed]

49. Levonmäki, M.; Hartikainen, H. Efficiency of liming in controlling the mobility of lead in shooting range soils as assessed by different experimental approaches. Sci. Total Environ. 2007, 388, 1-7. [CrossRef] [PubMed]

50. Miretzky, P.; Fernandez-Cirelli, A. Phosphates for Pb immobilization in soils: A review. Environ. Chem. Lett. 2008, 6, 121-133. [CrossRef]

51. Dinake, P.; Kelebemang, R. Critical assessment of mechanistic pathways for chemical remediation techniques applied to Pb impacted soils at shooting ranges-A review. Environ. Pollut. Bioavailab. 2019, 31, 282-305. [CrossRef]

52. European Union Directive 2008/98/EC of the European Parliament and of the Council, of 19 November 2008, on waste and repealing certain Directives. Fundam. Texts Eur. Priv. Law 2008, 3-30. [CrossRef]

53. European Commission Communication from the Commision to the European Parliament, the Council, the European Economic and Social Commitee and the Comintee of the Regions-Closing the Loop-An EU Action Plan for the Circular Economy COM(2015) 614; Official Journal of the European Communities: Brussels, Belgium, 2015; pp. 1-24. Available online: https://eur-lex.europa.eu/legalcontent/EN/TXT/?uri=CELEX:52015DC0614 (accessed on 24 March 2021).

54. United Nations (UN). The Sustainable Development Goals Report. 2016, 54, p. 56. Available online: https://unstats.un.org/ sdgs/report/2016/ (accessed on 24 March 2021). [CrossRef]

55. Moraga, G.; Huysveld, S.; Mathieux, F.; Blengini, G.A.; Alaerts, L.; Van Acker, K.; de Meester, S.; Dewulf, J. Circular economy indicators: What do they measure? Resour. Conserv. Recycl. 2019, 146, 452-461. [CrossRef]

56. European Commission Communication from the Commision to the European Parliament, the Council, the European Economic and Social Commitee and the Comintee of the Regions-The European Green Deal COM (2019)640; Official Journal of the European Communities: Brussels, Belgium, 2019; pp. 1-39. Available online: https:/ / eur-lex.europa.eu/legal-content/EN/TXT/?uri=CELEX:52019DC0 640 (accessed on 24 March 2021).

57. Camilleri, M.A. European environment policy for the circular economy: Implications for business and industry stakeholders. Sustain. Dev. 2020, 28, 1804-1812. [CrossRef]

58. Smol, M.; Marcinek, P.; Duda, J.; Szołdrowska, D. Correction: Smol, M.; et al. importance of sustainable mineral resource management in implementing the circular economy (ce) model and the european green deal strategy. (Resource 2020, 9, 55). Resources 2020, 9, 78. [CrossRef]

59. Kushwaha, A.; Hans, N.; Kumar, S.; Rani, R. A critical review on speciation, mobilization and toxicity of lead in soil-microbe-plant system and bioremediation strategies. Ecotoxicol. Environ. Saf. 2018, 147, 1035-1045. [CrossRef]

60. Zhang, H.; Young, S.D. Characterizing the availability of metals in contaminated soils. II. The soil solution. Soil Use Manag. 2006, 21, 459-467. [CrossRef]

61. Lago-Vila, M.; Rodríguez-Seijo, A.; Vega, F.A.; Arenas-Lago, D. Phytotoxicity assays with hydroxyapatite nanoparticles lead the way to recover firing range soils. Sci. Total Environ. 2019, 690, 1151-1161. [CrossRef] [PubMed]

62. Palansooriya, K.N.; Shaheen, S.M.; Chen, S.S.; Tsang, D.C.W.; Hashimoto, Y.; Hou, D.; Bolan, N.S.; Rinklebe, J.; Ok, Y.S. Soil amendments for immobilization of potentially toxic elements in contaminated soils: A critical review. Environ. Int. 2020, 134, 105046. [CrossRef]

63. Dinake, P.; Kelebemang, R.; Sehube, N. A comprehensive approach to speciation of lead and its contamination of firing range soils: A review. Soil Sediment Contam. 2019, 28, 431-459. [CrossRef]

64. Selonen, S.; Setälä, H. Soil processes and tree growth at shooting ranges in a boreal forest reflect contamination history and lead-induced changes in soil food webs. Sci. Total Environ. 2015, 518-519, 320-327. [CrossRef]

65. Hernandez-Allica, J.; Barrutia, O.; Becerril, J.M.; Garbisu, C. EDTA reduces the physiological damage of lead on cardoon plants grown hydroponically. J. Phys. IV JP 2003, 107, 613-616. [CrossRef] 
66. Gómez-Sagasti, M.T.; Alkorta, I.; Becerril, J.M.; Epelde, L.; Anza, M.; Garbisu, C. Microbial monitoring of the recovery of soil quality during heavy metal phytoremediation. Water Air Soil Pollut. 2012, 223, 3249-3262. [CrossRef]

67. Johnsen, I.V.; Aaneby, J. Soil intake in ruminants grazing on heavy-metal contaminated shooting ranges. Sci. Total Environ. 2019, 687, 41-49. [CrossRef] [PubMed]

68. Rodríguez-Seijo, A.; Alfaya, M.C.; Andrade, M.L.; Vega, F.A. Copper, chromium, nickel, lead and zinc levels and pollution degree in firing range soils. Land Degrad. Dev. 2016, 27, 1721-1730. [CrossRef]

69. Flora, G.; Gupta, D.; Tiwari, A. Toxicity of lead: A review with recent updates. Interdiscip. Toxicol. 2012, 5, 47-58. [CrossRef]

70. Gómez-Sagasti, M.T.; Hernández, A.; Artetxe, U.; Garbisu, C.; Becerril, J.M. How valuable are organic amendments as tools for the phytomanagement of degraded Soils? The knowns, known unknowns, and unknowns. Front. Sustain. Food Syst. 2018, 2, 1-16. [CrossRef]

71. Barrutia, O.; Garbisu, C.; Hernández-Allica, J.; García-Plazaola, J.I.; Becerril, J.M. Differences in EDTA-assisted metal phytoextraction between metallicolous and non-metallicolous accessions of Rumex acetosa L. Environ. Pollut. 2010, 158, 1710-1715. [CrossRef]

72. Gul, I.; Manzoor, M.; Kallerhoff, J.; Arshad, M. Enhanced phytoremediation of lead by soil applied organic and inorganic amendments: $\mathrm{Pb}$ phytoavailability, accumulation and metal recovery. Chemosphere 2020, 258, 127405. [CrossRef]

73. Rantalainen, M.L.; Torkkeli, M.; Strömmer, R.; Setälä, H. Lead contamination of an old shooting range affecting the local ecosystem-A case study with a holistic approach. Sci. Total Environ. 2006, 369, 99-108. [CrossRef] [PubMed]

74. Okkenhaug, G.; Smebye, A.B.; Pabst, T.; Amundsen, C.E.; Sævarsson, H.; Breedveld, G.D. Shooting range contamination: Mobility and transport of lead $(\mathrm{Pb})$, copper $(\mathrm{Cu})$ and antimony $(\mathrm{Sb})$ in contaminated peatland. J. Soils Sediments 2018, 18, 3310-3323. [CrossRef]

75. Labare, M.P.; Butkus, M.A.; Riegner, D.; Schommer, N.; Atkinson, J. Evaluation of lead movement from the abiotic to biotic at a small-arms firing range. Environ. Geol. 2004, 46, 750-754. [CrossRef]

76. Peddicord, R.K.; LaKind, J.S. Ecological and human health risks at an outdoor firing range. Environ. Toxicol. Chem. 2000, 19, 2602-2613. [CrossRef]

77. Bennett, J.R.; Kaufman, C.A.; Koch, I.; Sova, J.; Reimer, K.J. Ecological risk assessment of lead contamination at rifle and pistol ranges using techniques to account for site characteristics. Sci. Total Environ. 2007, 374, 91-101. [CrossRef] [PubMed]

78. Chang, L.W.; Meier, J.R.; Smith, M.K. Application of plant and earthworm bioassays to evaluate remediation of a leadcontaminated soil. Arch. Environ. Contam. Toxicol. 1997, 32, 166-171. [CrossRef] [PubMed]

79. Gómez-Sagasti, M.T.; Epelde, L.; Alkorta, I.; Garbisu, C. Reflections on soil contamination research from a biologist's point of view. Appl. Soil Ecol. 2016, 105, 207-210. [CrossRef]

80. Moon, D.H.; Park, J.W.; Cheong, K.H.; Hyun, S.; Koutsospyros, A.; Park, J.H.; Ok, Y.S. Stabilization of lead and copper contaminated firing range soil using calcined oyster shells and fly ash. Environ. Geochem. Health 2013, 35, 705-714. [CrossRef] [PubMed]

81. Clemente, R.; Pardo, T.; Madejón, P.; Madejón, E.; Bernal, M.P. Food byproducts as amendments in trace elements contaminated soils. Food Res. Int. 2015, 73, 176-189. [CrossRef]

82. Ahmad, M.; Moon, D.H.; Lim, K.J.; Shope, C.L.; Lee, S.S.; Usman, A.R.A.; Kim, K.R.; Park, J.H.; Hur, S.O.; Yang, J.E.; et al. An assessment of the utilization of waste resources for the immobilization of $\mathrm{Pb}$ and $\mathrm{Cu}$ in the soil from a Korean military shooting range. Environ. Earth Sci. 2012, 67, 1023-1031. [CrossRef]

83. Moon, D.H.; Cheong, K.H.; Khim, J.; Wazne, M.; Hyun, S.; Park, J.H.; Chang, Y.Y.; Ok, Y.S. Stabilization of Pb ${ }^{2+}$ and Cu ${ }^{2+}$ contaminated firing range soil using calcined oyster shells and waste cow bones. Chemosphere 2013, 91, 1349-1354. [CrossRef]

84. Moon, D.H.; Cheong, K.H.; Koutsospyros, A.; Chang, Y.Y.; Hyun, S.; Ok, Y.S.; Park, J.H. Assessment of waste oyster shells and coal mine drainage sludge for the stabilization of As-, $\mathrm{Pb}-$, and $\mathrm{Cu}-$ contaminated soil. Environ. Sci. Pollut. Res. 2016, 23, 2362-2370. [CrossRef]

85. Lee, K.Y.; Moon, D.H.; Lee, S.H.; Kim, K.W.; Cheong, K.H.; Park, J.H.; Ok, Y.S.; Chang, Y.Y. Simultaneous stabilization of arsenic, lead, and copper in contaminated soil using mixed waste resources. Environ. Earth Sci. 2013, 69, 1813-1820. [CrossRef]

86. Ahmad, M.; Hashimoto, Y.; Moon, D.H.; Lee, S.S.; Ok, Y.S. Immobilization of lead in a Korean military shooting range soil using eggshell waste: An integrated mechanistic approach. J. Hazard. Mater. 2012, 209-210, 392-401. [CrossRef]

87. Ahmad, M.; Lee, S.S.; Lim, J.E.; Lee, S.E.; Cho, J.S.; Moon, D.H.; Hashimoto, Y.; Ok, Y.S. Speciation and phytoavailability of lead and antimony in a small arms range soil amended with mussel shell, cow bone and biochar: EXAFS spectroscopy and chemical extractions. Chemosphere 2014, 95, 433-441. [CrossRef]

88. Hashimoto, Y.; Taki, T.; Sato, T. Sorption of dissolved lead from shooting range soils using hydroxyapatite amendments synthesized from industrial byproducts as affected by varying $\mathrm{pH}$ conditions. J. Environ. Manag. 2009, 90, 1782-1789. [CrossRef]

89. Hashimoto, Y.; Taki, T.; Sato, T. Extractability and leachability of $\mathrm{Pb}$ in a shooting range soil amended with poultry litter ash: Investigations for immobilization potentials. J. Environ. Sci. Health Part A Toxic/Hazard. Subst. Environ. Eng. 2009, 44, 583-590. [CrossRef]

90. Cao, X.; Ma, L.; Liang, Y.; Gao, B.; Harris, W. Simultaneous immobilization of lead and atrazine in contaminated soils using dairy-manure biochar. Environ. Sci. Technol. 2011, 45, 4884-4889. [CrossRef] [PubMed]

91. Uchimiya, M.; Bannon, D.I.; Wartelle, L.H.; Lima, I.M.; Klasson, K.T. Lead retention by broiler litter biochars in small arms range soil: Impact of pyrolysis temperature. J. Agric. Food Chem. 2012, 60, 5035-5044. [CrossRef] 
92. Lee, S.-E.; Ahmad, M.; Usman, A.A.R.A.; Awad, Y.M.; Min, S.-H.; Yang, J.-E.; Lee, S.-S.; Ok, Y.-S. Effects of biochar on soil quality and heavy metal availability in a military shooting range soil in Korea. Korean J. Soil Sci. Fertil. 2011, 44, 67-77. [CrossRef]

93. Moon, D.H.; Park, J.W.; Chang, Y.Y.; Ok, Y.S.; Lee, S.S.; Ahmad, M.; Koutsospyros, A.; Park, J.H.; Baek, K. Immobilization of lead in contaminated firing range soil using biochar. Environ. Sci. Pollut. Res. 2013, 20, 8464-8471. [CrossRef]

94. Ahmad, M.; Ok, Y.S.; Rajapaksha, A.U.; Lim, J.E.; Kim, B.Y.; Ahn, J.H.; Lee, Y.H.; Al-Wabel, M.I.; Lee, S.E.; Lee, S.S. Lead and copper immobilization in a shooting range soil using soybean stover- and pine needle-derived biochars: Chemical, microbial and spectroscopic assessments. J. Hazard. Mater. 2016, 301, 179-186. [CrossRef]

95. Ahmad, M.; Lee, S.S.; Lee, S.E.; Al-Wabel, M.I.; Tsang, D.C.W.; Ok, Y.S. Biochar-induced changes in soil properties affected immobilization/mobilization of metals/metalloids in contaminated soils. J. Soils Sediments 2017, 17, 717-730. [CrossRef]

96. Vithanage, M.; Herath, I.; Almaroai, Y.A.; Rajapaksha, A.U.; Huang, L.; Sung, J.K.; Lee, S.S.; Ok, Y.S. Effects of carbon nanotube and biochar on bioavailability of $\mathrm{Pb}, \mathrm{Cu}$ and $\mathrm{Sb}$ in multi-metal contaminated soil. Environ. Geochem. Health 2017, 39, 1409-1420. [CrossRef]

97. Silvani, L.; Cornelissen, G.; Botnen Smebye, A.; Zhang, Y.; Okkenhaug, G.; Zimmerman, A.R.; Thune, G.; Sævarsson, H.; Hale, S.E. Can biochar and designer biochar be used to remediate per- and polyfluorinated alkyl substances (PFAS) and lead and antimony contaminated soils? Sci. Total Environ. 2019, 694, 133693. [CrossRef] [PubMed]

98. Hou, D.; Al-Tabbaa, A. Sustainability: A new imperative in contaminated land remediation. Environ. Sci. Policy 2014, 39, 25-34. [CrossRef]

99. Shaheen, S.M.; Hooda, P.S.; Tsadilas, C.D. Opportunities and challenges in the use of coal fly ash for soil improvements-A review. J. Environ. Manag. 2014, 145, 249-267. [CrossRef]

100. Pandey, V.C.; Singh, K.; Singh, R.P.; Singh, B. Naturally growing Saccharum munja L. on the fly ash lagoons: A potential ecological engineer for the revegetation and stabilization. Ecol. Eng. 2012, 40, 95-99. [CrossRef]

101. Bhattacharjee, U.; Kandpal, T.C. Potential of fly ash utilisation in India. Energy 2002, 27, 151-166. [CrossRef]

102. Wang, S. Application of solid ash based catalysts in heterogeneous catalysis. Environ. Sci. Technol. 2008, 42, 7055-7063. [CrossRef] [PubMed]

103. Yao, Z.T.; Ji, X.S.; Sarker, P.K.; Tang, J.H.; Ge, L.Q.; Xia, M.S.; Xi, Y.Q. A comprehensive review on the applications of coal fly ash. Earth Sci. Rev. 2015, 141, 105-121. [CrossRef]

104. Gatima, E.; Mwinyihija, M.; Killham, K. Assessment of pulverised fly ash (PFA) as an ameliorant of lead contaminated soils. Am. J. Environ. Sci. 2005, 1, 230-238. [CrossRef]

105. Kumpiene, J.; Lagerkvist, A.; Maurice, C. Stabilization of Pb- and Cu-contaminated soil using coal fly ash and peat. Environ. Pollut. 2007, 145, 365-373. [CrossRef]

106. Ram, L.C.; Masto, R.E. An appraisal of the potential use of fly ash for reclaiming coal mine spoil. J. Environ. Manag. 2010, 91, 603-617. [CrossRef]

107. Ram, L.C.; Masto, R.E. Fly ash for soil amelioration: A review on the influence of ash blending with inorganic and organic amendments. Earth Sci. Rev. 2014, 128, 52-74. [CrossRef]

108. Skousen, J.; Ziemkiewicz, P.; Yang, J.E. Use of coal combustion by-products in mine reclamation: Review of case studies in the USA. Geosystem. Eng. 2012, 15, 71-83. [CrossRef]

109. Dermatas, D.; Meng, X. Utilization of fly ash for stabilization/solidification of heavy metal contaminated soils. Eng. Geol. 2003, 70, 377-394. [CrossRef]

110. Ciccu, R.; Ghiani, M.; Serci, A.; Fadda, S.; Peretti, R.; Zucca, A. Heavy metal immobilization in the mining-contaminated soils using various industrial wastes. Miner. Eng. 2003, 16, 187-192. [CrossRef]

111. Moon, D.H.; Dermatas, D. An evaluation of lead leachability from stabilized/solidified soils under modified semi-dynamic leaching conditions. Eng. Geol. 2006, 85, 67-74. [CrossRef]

112. Moon, D.H.; Dermatas, D. Arsenic and lead release from fly ash stabilized/solidified soils under modified semi-dynamic leaching conditions. J. Hazard. Mater. 2007, 141, 388-394. [CrossRef]

113. Shaheen, S.M.; Rinklebe, J. Impact of emerging and low cost alternative amendments on the (im)mobilization and phytoavailability of $\mathrm{Cd}$ and $\mathrm{Pb}$ in a contaminated floodplain soil. Ecol. Eng. 2015, 74, 319-326. [CrossRef]

114. Pandey, V.C.; Singh, N. Impact of fly ash incorporation in soil systems. Agric. Ecosyst. Environ. 2010, 136, 16-27. [CrossRef]

115. Akinci, A.; Artir, R. Characterization of trace elements and radionuclides and their risk assessment in red mud. Mater. Charact. 2008, 59, 417-421. [CrossRef]

116. Hua, Y.; Heal, K.V.; Friesl-Hanl, W. The use of red mud as an immobiliser for metal/metalloid-contaminated soil: A review. J. Hazard. Mater. 2017, 325, 17-30. [CrossRef]

117. Kong, X.; Guo, Y.; Xue, S.; Hartley, W.; Wu, C.; Ye, Y.; Cheng, Q. Natural evolution of alkaline characteristics in bauxite residue. J. Clean. Prod. 2017, 143, 224-230. [CrossRef]

118. Power, G.; Gräfe, M.; Klauber, C. Bauxite residue issues: I. Current management, disposal and storage practices. Hydrometallurgy 2011, 108, 33-45. [CrossRef]

119. Liu, Y.; Naidu, R. Hidden values in bauxite residue (red mud): Recovery of metals. Waste Manag. 2014, 34, 2662-2673. [CrossRef] [PubMed]

120. Kinnarinen, T.; Lubieniecki, B.; Holliday, L.; Helsto, J.J.; Häkkinen, A. Recovery of sodium from bauxite residue by pressure filtration and cake washing. Int. J. Miner. Process. 2015, 141, 20-26. [CrossRef] 
121. Feigl, V.; Anton, A.; Uzigner, N.; Gruiz, K. Red mud as a chemical stabilizer for soil contaminated with toxic metals. Water Air Soil Pollut. 2012, 223, 1237-1247. [CrossRef]

122. Lockwood, C.L.; Mortimer, R.J.G.; Stewart, D.I.; Mayes, W.M.; Peacock, C.L.; Polya, D.A.; Lythgoe, P.R.; Lehoux, A.P.; Gruiz, K.; Burke, I.T. Mobilisation of arsenic from bauxite residue (red mud) affected soils: Effect of $\mathrm{pH}$ and redox conditions. Appl. Geochem. 2014, 51, 268-277. [CrossRef]

123. Taneez, M.; Hurel, C. A review on the potential uses of red mud as amendment for pollution control in environmental media. Environ. Sci. Pollut. Res. 2019, 26, 22106-22125. [CrossRef] [PubMed]

124. Lombi, E.; Zhao, F.J.; Zhang, G.; Sun, B.; Fitz, W.; Zhang, H.; McGrath, S.P. In situ fixation of metals in soils using bauxite residue: Chemical assessment. Environ. Pollut. 2002, 118, 435-443. [CrossRef]

125. Tsakiridis, P.E.; Agatzini-Leonardou, S.; Oustadakis, P. Red mud addition in the raw meal for the production of Portland cement clinker. J. Hazard. Mater. 2004, 116, 103-110. [CrossRef] [PubMed]

126. Zhang, N.; Sun, H.; Liu, X.; Zhang, J. Early-age characteristics of red mud-coal gangue cementitious material. J. Hazard. Mater. 2009, 167, 927-932. [CrossRef]

127. Deelwal, K.; Dharavath, K.; Kulshreshtha, M. Evaluation of characteristic properties of red mud for possible use as a geotechnical material in civil construction. Int. J. Adv. Eng. Technol. 2014, 7, 1053-1059.

128. Mukiza, E.; Zhang, L.L.; Liu, X.; Zhang, N. Utilization of red mud in road base and subgrade materials: A review. Resour. Conserv. Recycl. 2019, 141, 187-199. [CrossRef]

129. Clark, M.W.; Johnston, M.; Reichelt-Brushett, A.J. Comparison of several different neutralisations to a bauxite refinery residue: Potential effectiveness environmental ameliorants. Appl. Geochem. 2015, 56, 1-10. [CrossRef]

130. Bertocchi, A.F.; Ghiani, M.; Peretti, R.; Zucca, A. Red mud and fly ash for remediation of mine sites contaminated with As, Cd, $\mathrm{Cu}, \mathrm{Pb}$ and $\mathrm{Zn}$. J. Hazard. Mater. 2006, 134, 112-119. [CrossRef]

131. Tandy, S.; Meier, N.; Schulin, R. Use of soil amendments to immobilize antimony and lead in moderately contaminated shooting range soils. J. Hazard. Mater. 2017, 324, 617-625. [CrossRef]

132. Sorvari, J. Developing environmental legislation to promote recycling of industrial by-products-An endless story? Waste Manag. 2008, 28, 489-501. [CrossRef]

133. Ahmaruzzaman, M. A review on the utilization of fly ash. Prog. Energy Combust. Sci. 2010, 36, 327-363. [CrossRef]

134. Stenmarck, Å.; Jensen, C.; Quested, T.; Moates, G.; Cseh, B.; Juul, S.; Parry, A.; Politano, A.; Redlingshofer, B.; Scherhaufer, S.; et al. Estimates of European Food Waste Levels; FUSIONS: Stockholm, Sweden, 2016. Available online: http://www.eu-fusions.org/ phocadownload/Publications /Estimates\%20of\%20European\%20food\%20waste\%20levels.pdf (accessed on 24 March 2021).

135. Xu, L.; Geelen, D. Developing biostimulants from agro-food and industrial by-products. Front. Plant Sci. 2018, 871, 1-13. [CrossRef]

136. O'Connor, J.; Hoang, S.A.; Bradney, L.; Dutta, S.; Xiong, X.; Tsang, D.C.W.; Ramadass, K.; Vinu, A.; Kirkham, M.B.; Bolan, N.S. A review on the valorisation of food waste as a nutrient source and soil amendment. Environ. Pollut. 2021, 272, 115985. [CrossRef] [PubMed]

137. Scherhaufer, S.; Moates, G.; Hartikainen, H.; Waldron, K.; Obersteiner, G. Environmental impacts of food waste in Europe. Waste Manag. 2018, 77, 98-113. [CrossRef]

138. Melikoglu, M.; Lin, C.S.K.; Webb, C. Analysing global food waste problem: Pinpointing the facts and estimating the energy content. Cent. Eur. J. Eng. 2013, 3, 157-164. [CrossRef]

139. Mirabella, N.; Castellani, V.; Sala, S. Current options for the valorization of food manufacturing waste: A review. J. Clean. Prod. 2014, 65, 28-41. [CrossRef]

140. FAO. Energy-Smart Food for People and Climate. Issue Paper. FAO/Office of Knowledge Exchange, Research and Extension: Rome, Italy, 2011; p. 78. Available online: http:/ /www.fao.org/docrep/014/i2454e/i2454e00.pdf (accessed on 24 March 2021).

141. Munesue, Y.; Masui, T.; Fushima, T. The effects of reducing food losses and food waste on global food insecurity, natural resources, and greenhouse gas emissions. Environ. Econ. Policy Stud. 2015, 17, 43-77. [CrossRef]

142. Bernstad, A.; la Cour Jansen, J. A life cycle approach to the management of household food waste-A Swedish full-scale case study. Waste Manag. 2011, 31, 1879-1896. [CrossRef] [PubMed]

143. Makarichi, L.; Jutidamrongphan, W.; Techato, K. The evolution of waste-to-energy incineration: A review. Renew. Sustain. Energy Rev. 2018, 91, 812-821. [CrossRef]

144. Arancon, R.A.D.; Lin, C.S.K.; Chan, K.M.; Kwan, T.H.; Luque, R. Advances on waste valorization: New horizons for a more sustainable society. Energy Sci. Eng. 2013, 1, 53-71. [CrossRef]

145. Capson-Tojo, G.; Rouez, M.; Crest, M.; Steyer, J.P.; Delgenès, J.P.; Escudié, R. Food waste valorization via anaerobic processes: A review. Rev. Environ. Sci. Biotechnol. 2016, 15, 499-547. [CrossRef]

146. European Commission Communication from the Commision to the Council and the European Parliament-Integrated Product PolicyBuilding on Environmental Life-Cycle Thinking COM (2003)302; Official Journal of the European Community: Brussels, Belgium, 2003; pp. 1-30. Available online: http:/ / eur-lex.europa.eu/legal-content/EN/TXT/?uri=CELEX:52001DC0068 (accessed on 24 March 2021). 
147. European Commission Communication from the Commision to the European Parliament, the Council, the European Economic and Social Commitee and the Comintee of the Regions-Roadmap to a Resource Efficient Europe COM(2011) 571; Official Journal of the European Community: Brussels, Belgium, 2011; pp. 1-21. Available online: https://eur-lex.europa.eu/legal-content/EN/TXT/?uri= CELEX\%3A52011DC0571 (accessed on 24 March 2021).

148. European Commission EUROPE 2020-A European Strategy for Smart, Sustainable and Inclusive Growth COM (2010) 2020; Official Journal of the European Community: Brussels, Belgium, 2020; pp. 1-40. Available online: https://eur-lex.europa.eu/legalcontent/en/ALL/?uri=CELEX\%3A52010DC2020 (accessed on 24 March 2021).

149. European Commission Communication from the Commision to the European Parliament, the Council, the European Economic and Social Commitee and the Comintee of the Regions-Innovating for Sustainable Growth: A Bioeconomy for Europe COM (2012) 060; European Commission: Brussels, Belgium, 2012; pp. 1-64. Available online: https://eur-lex.europa.eu/legal-content/EN/TXT/?uri= CELEX\%3A52012DC0060 (accessed on 24 March 2021). [CrossRef]

150. Ganapathi, H.; Phukan, M. Environmental Hazards of Limestone Mining and Adaptive Practices for Environment Management Plan BT-Environmental Processes and Management: Tools and Practices; Singh, R.M., Shukla, P., Singh, P., Eds.; Springer International Publishing: Cham, Switzerland, 2020; pp. 121-134. ISBN 978-3-030-38152-3.

151. Quina, M.J.; Soares, M.A.R.; Quinta-Ferreira, R. Applications of industrial eggshell as a valuable anthropogenic resource. Resour. Conserv. Recycl. 2017, 123, 176-186. [CrossRef]

152. Yao, Z.; Xia, M.; Li, H.; Chen, T.; Ye, Y.; Zheng, H. Bivalve shell: Not an abundant useless waste but a functional and versatile biomaterial. Crit. Rev. Environ. Sci. Technol. 2014, 44, 2502-2530. [CrossRef]

153. Mo, K.H.; Alengaram, U.J.; Jumaat, M.Z.; Lee, S.C.; Goh, W.I.; Yuen, C.W. Recycling of seashell waste in concrete: A review. Constr. Build. Mater. 2018, 162, 751-764. [CrossRef]

154. Ok, Y.S.; Oh, S.E.; Ahmad, M.; Hyun, S.; Kim, K.R.; Moon, D.H.; Lee, S.S.; Lim, K.J.; Jeon, W.T.; Yang, J.E. Effects of natural and calcined oyster shells on $\mathrm{Cd}$ and $\mathrm{Pb}$ immobilization in contaminated soils. Environ. Earth Sci. 2010, 61, 1301-1308. [CrossRef]

155. Ok, Y.S.; Kim, S.C.; Kim, D.K.; Skousen, J.G.; Lee, J.S.; Cheong, Y.W.; Kim, S.J.; Yang, J.E. Ameliorants to immobilize Cd in rice paddy soils contaminated by abandoned metal mines in Korea. Environ. Geochem. Health 2011, 33, 23-30. [CrossRef]

156. Ok, Y.S.; Lee, S.S.; Jeon, W.T.; Oh, S.E.; Usman, A.R.A.; Moon, D.H. Application of eggshell waste for the immobilization of cadmium and lead in a contaminated soil. Environ. Geochem. Health 2011, 33, 31-39. [CrossRef]

157. Verma, N.; Kumar, V.; Bansal, M.C. Utilization of egg shell waste in cellulase production by neurospora crassa under wheat bran-based solid state fermentation. Polish J. Environ. Stud. 2012, 21, 491-497.

158. Chrysochoou, M.; Dermatas, D.; Grubb, D.G. Phosphate application to firing range soils for Pb immobilization: The unclear role of phosphate. J. Hazard. Mater. 2007, 144, 1-14. [CrossRef]

159. Hodson, M.E.; Valsami-Jones, E.; Cotter-Howells, J.D.; Dubbin, W.E.; Kemp, A.J.; Thornton, I.; Warren, A. Effect of bone meal (calcium phosphate) amendments on metal release from contaminated soils-A leaching column study. Environ. Pollut. 2001, 112, 233-243. [CrossRef]

160. Shackley, S.; Carter, S.; Knowles, T.; Middelink, E.; Haefele, S.; Sohi, S.; Cross, A.; Haszeldine, S. Sustainable gasification-biochar systems? A case-study of rice-husk gasification in Cambodia, Part I: Context, chemical properties, environmental and health and safety issues. Energy Policy 2012, 42, 49-58. [CrossRef]

161. Cha, J.S.; Park, S.H.; Jung, S.C.; Ryu, C.; Jeon, J.K.; Shin, M.C.; Park, Y.K. Production and utilization of biochar: A review. J. Ind. Eng. Chem. 2016, 40,1-15. [CrossRef]

162. Hassan, M.; Liu, Y.; Naidu, R.; Parikh, S.J.; Du, J.; Qi, F.; Willett, I.R. Influences of feedstock sources and pyrolysis temperature on the properties of biochar and functionality as adsorbents: A meta-analysis. Sci. Total Environ. 2020, 744, 140714. [CrossRef] [PubMed]

163. Yaashikaa, P.R.; Kumar, P.S.; Varjani, S.; Saravanan, A. A critical review on the biochar production techniques, characterization, stability and applications for circular bioeconomy. Biotechnol. Rep. 2020, 28, e00570. [CrossRef]

164. Purakayastha, T.J.; Bera, T.; Bhaduri, D.; Sarkar, B.; Mandal, S.; Wade, P.; Kumari, S.; Biswas, S.; Menon, M.; Pathak, H.; et al. A review on biochar modulated soil condition improvements and nutrient dynamics concerning crop yields: Pathways to climate change mitigation and global food security. Chemosphere 2019, 227, 345-365. [CrossRef]

165. Cheng, S.; Chen, T.; Xu, W.; Huang, J.; Jiang, S.; Yan, B. Application research of biochar for the remediation of soil heavy metals contamination: A review. Molecules 2020, 25, 3167. [CrossRef] [PubMed]

166. El-Naggar, A.; Lee, S.S.; Rinklebe, J.; Farooq, M.; Song, H.; Sarmah, A.K.; Zimmerman, A.R.; Ahmad, M.; Shaheen, S.M.; Ok, Y.S Biochar application to low fertility soils: A review of current status, and future prospects. Geoderma 2019, 337, 536-554. [CrossRef]

167. Palansooriya, K.N.; Wong, J.T.F.; Hashimoto, Y.; Huang, L.; Rinklebe, J.; Chang, S.X.; Bolan, N.; Wang, H.; Ok, Y.S. Response of microbial communities to biochar-amended soils: A critical review. Biochar 2019, 1, 3-22. [CrossRef]

168. Leng, L.; Xu, X.; Wei, L.; Fan, L.; Huang, H.; Li, J.; Lu, Q.; Li, J.; Zhou, W. Biochar stability assessment by incubation and modelling: Methods, drawbacks and recommendations. Sci. Total Environ. 2019, 664, 11-23. [CrossRef] [PubMed]

169. Kuppusamy, S.; Thavamani, P.; Megharaj, M.; Venkateswarlu, K.; Naidu, R. Agronomic and remedial benefits and risks of applying biochar to soil: Current knowledge and future research directions. Environ. Int. 2016, 87, 1-12. [CrossRef] [PubMed]

170. Godlewska, P.; Ok, Y.S.; Oleszczuk, P. The dark side of black gold: Ecotoxicological aspects of biochar and biochar-amended soils. J. Hazard. Mater. 2021, 403, 123833. [CrossRef] 
171. Meyer, S.; Genesio, L.; Vogel, I.; Schmidt, H.P.; Soja, G.; Someus, E.; Shackley, S.; Verheijen, F.G.A.; Glaser, B. Biochar standardization and legislation harmonization. J. Environ. Eng. Landsc. Manag. 2017, 25, 175-191. [CrossRef]

172. Guitart, R.; Mateo, R. El empleo de Plomo en deportes como causa de intoxicación y de contaminación. Apunt. Cienc. Tecnol. 2006, 21, 2-8. (In Spanish)

173. Guitart, R.; Thomas, V.G. ¿Es el plomo empleado en deportes (caza, tiro y pesca deportiva) un problema de salud pública infravalorado? Rev. Española Salud Pública 2005, 79, 621-632. (In Spanish) [CrossRef]

174. Rodríguez-Seijo, A.; Cachada, A.; Gavina, A.; Duarte, A.C.; Vega, F.A.; Andrade, M.L.; Pereira, R. Lead and PAHs contamination of an old shooting range: A case study with a holistic approach. Sci. Total Environ. 2017, 575, 367-377. [CrossRef]

175. Sustainable Hunting and Biodiversity Foundation of the Basque Country (FUNCASBIOD). El Impacto Socioeconómico de la Actividad Cinegética Vasca. 2016. Available online: https://www.euskadi.eus/contenidos/nota_prensa/estudio_socioeconomico_caza/es_ def/adjuntos/ESTUDIO_IMPACTO_CINEGETICO_CAE.pdf (accessed on 24 March 2021). (In Spanish).

176. Vangronsveld, J.; Herzig, R.; Weyens, N.; Boulet, J.; Adriaensen, K.; Ruttens, A.; Thewys, T.; Vassilev, A.; Meers, E.; Nehnevajova, E.; et al. Phytoremediation of contaminated soils and groundwater: Lessons from the field. Environ. Sci. Pollut. Res. 2009, 16, 765-794. [CrossRef]

177. Kidd, P.; Mench, M.; Álvarez-López, V.; Bert, V.; Dimitriou, I.; Friesl-Hanl, W.; Herzig, R.; Olga Janssen, J.; Kolbas, A.; Müller, I.; et al. Agronomic practices for improving gentle remediation of trace element-contaminated soils. Int. J. Phytoremediat. 2015, 17, 1005-1037. [CrossRef] [PubMed]

178. Mench, M.J.; Dellise, M.; Bes, C.M.; Marchand, L.; Kolbas, A.; Coustumer, P.L.; Oustrière, N. Phytomanagement and remediation of $\mathrm{Cu}$-contaminated soils by high yielding crops at a former wood preservation site: Sunflower biomass and ionome. Front. Ecol. Evol. 2018, 6. [CrossRef]

179. Garbisu, C.; Alkorta, I.; Kidd, P.; Epelde, L.; Mench, M. Keep and promote biodiversity at polluted sites under phytomanagement. Environ. Sci. Pollut. Res. 2020, 27, 44820-44834. [CrossRef] [PubMed]

180. Burges, A.; Epelde, L.; Blanco, F.; Becerril, J.M.; Garbisu, C. Ecosystem services and plant physiological status during endophyteassisted phytoremediation of metal contaminated soil. Sci. Total Environ. 2017, 584-585, 329-338. [CrossRef] [PubMed]

181. Government of the Basque Country Law 4/2015, of 25 June, for the prevention and correction of soil pollution. Off. Bull. Spain $B O E-A-2015-8272$ 2015, 176, 62274-62311. (In Spanish) 